\title{
Logistics Models for the Transportation of Radioactive Waste and Spent Fuel
}
D. S. Joy
B. D. Holcomb

\section{OAK RIDGE NATIONAL LABORATORY} OPERATED BY UNION CARBIDE CORPORATION · FOR THE DEPARTMENT OF ENERGY 


\section{DISCLAIMER}

This report was prepared as an account of work sponsored by an agency of the United States Government. Neither the United States Government nor any agency Thereof, nor any of their employees, makes any warranty, express or implied, or assumes any legal liability or responsibility for the accuracy, completeness, or usefulness of any information, apparatus, product, or process disclosed, or represents that its use would not infringe privately owned rights. Reference herein to any specific commercial product, process, or service by trade name, trademark, manufacturer, or otherwise does not necessarily constitute or imply its endorsement, recommendation, or favoring by the United States Government or any agency thereof. The views and opinions of authors expressed herein do not necessarily state or reflect those of the United States Government or any agency thereof. 


\section{DISCLAIMER}

Portions of this document may be illegible in electronic image products. Images are produced from the best available original document. 
Printed in the United States of America. Available from National Technical Information Service

U.S. Department of Commerce

5285 Port Royal Road, Springfield, Virginia 22161

Price: Printed Copy $\$ 5.25$; Microfiche $\$ 3.00$

This report was prepared as an account of work sponsored by an agency of the United States Government. Neither the United States Government nor any agency thereof, nor any of their employees, contractors, subcontractors, or their employees, makes any warranty, express or implied, nor assumes any legal liability or responsibility for any third party's use nr the results of such use of any information, apparatus, product or process disclosed in this report, nor represents that its use by such lhird party would not-infringe privately owned rights. 
Contract No. W-7405-eng-26

CHEMICAL TECHNOLOGY DIVISION

Pilot Plant Section

LOGISTICS MODELS FOR THE TRANSPORTATION

OF RADIOACTIVE WASTE AND SPENT FUEL

D. S. Joy

B. D. Hol comb

\title{
Date Published - March 1978
}

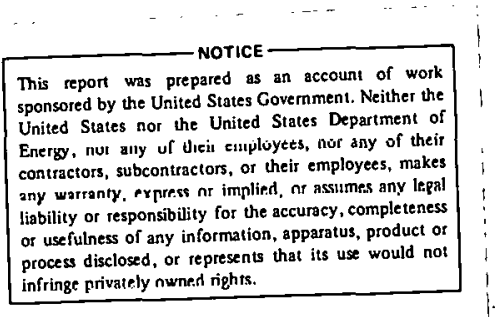

NOTICE Thls document contains information of a preliminary nature. It is subject to revision or correction and therefore does not represent a final report.

\author{
OAK RIDGE NATIONAL LABORATORY \\ Oak Ridge, Tennessee 37830 \\ operated by \\ UNION CARBIDE CORPORATION \\ for the \\ DEPARTMENT OF ENERGY
}




\section{THIS PAGE \\ WAS INTENTIONALLY \\ LEFT BLANK}


TABLE OF CONTENTS

$\underline{\text { Page }}$

FOREWORD . . . . . . . . . . . . . . . . . . . . . V v

ABSTRACT . . . . . . . . . . . . . . . . . . . . . 1

1. INTRODUCTION . . . . . . . . . . . . . . . . . . . 1

2. LOW-LEVEL WASTE LOGISTICS MODEL . . . . . . . . . . . . 3

2.1 General Description . . . . . . . . . . . . . 3

2.2 Mathematical Model . . . . . . . . . . . . . 4

2.3 Data Requirements . . . . . . . . . . . . . . 6

2.4 Organization of Output . . . . . . . . . . . . . . . 7

2.5 Sample Problem ... . . . . . . . . . . . . 8

3. SPENT FUEL LOGISTICS MODEL . . . . . . . . . . . . . . . . . . 19

3.1 General Description . . . . . . . . . . . . . . . 19

3.2 Mathematical Model . . . . . . . . . . . . . . 23

3.3 Data Requirements . . . . . . . . . . . . . . . 26

3.4 Organization of Output . . . . . . . . . . . . . 27

3.5 Sample Problem .................... . 27

4. SPENT FUEL SHIPMENT PROGRAM . . . . . . . . . . . . . . . 38

4.1 Program Description . . . . . . . . . . . . . . . . 41

4.2 Mathematical Basis . . . . . . ........ . 41

4.3 Data kequirements .. . . . . . . . . . . . . . 44

4.4 Program Output . . . . . . . . . . . . . . . . . . 45

5. NUCLEAR REACTOR DATA BASE . . . . . . . . . . . . . . . . . 46

6. SUMMARY ....................... . . 46

7. REFERENCFS . . . . . . . . . . . . . . . . . 48 
THIS PAGE

\section{WAS INTENTIONALLY \\ LEFT BLANK}




\section{FOREWORD}

This report was prepared by the Oak Ridge National Laboratory (ORNL) in cooperation with the Office of Waste Isolation (OWI) and is part of the National Waste Terminal Storage (NWTS) Program. The principal objective of the NWTS Program is to establish facilities in various deep geologic formations at several locations in the United States which will safely dispose of commercial radioactive wastes. According to federal regulations, such wastes must be delivered to a federal repository for terminal storage. The OWI Transportation/Logistics Study addresses problems associated with shipping these wastes to NWTS facilities.

The objective of the Transportation/Logisitics Study is to ensure the availability of a viable system for transporting the wastes to federal repositories. In order to accomplish this objective, a systems analysis of waste transportation has been directed by ORNL to determine the problems that must be solved and to develop a program plan to identify the order in which these studies should be pursued. An important part of the Transportation Program is logistics. This report describes the logistics models that have been developed to support the Transportation Program. 


\title{
LOGISTICS MODELS FOR THE TRANSPORTATION OF RADIOACTIVE WASTE AND SPENT FUEL
}

\author{
D. S. Joy
}

B. Holcomb

\begin{abstract}
Mathematical modeling of the logistics of waste shipment is an effective way to provide input to program planning and long-range waste management. Several logistics models have been developed for use in parametric studies, contingency planning, and management of transportation networks. These models allow the determination of shipping schedules, optimal routes, probable transportation modes, minimal costs, minimal personnel exposure, minimal transportation equipment, etc. Such information will permit OWI to specify waste-receiving rates at various repositories in order to balance work loads, evaluate surge capacity requirements, and estimate projected shipping cask fleets. The programs are tailored to utilize information on the types of wastes being received, location of repositories and waste-generating facilities, shipping distances, time required for a given shipment, availability of equipment, above-ground storage capabilities and locations, projected waste throughput rates, etc.

Two basic models have been developed. The Low-Level Waste Model evaluates the optimal transportation policy for shipping waste directly from the source to a final destination without any intermediate stops. The Spent Fuel Logistics Model evaluates the optimal transportation policy for shipping unreprocessed spent fuel from nuclear power plants (1) indirectly, that is, to an Away-From-Reactor (AFR.) storage facility, with subsequent transhipment to a repository, or (2) directly to a repository.
\end{abstract}

\section{INTRODUCTION}

Waste transport will constitute an important part of the nuclear industry, irrespective of the options regarding fuel reprocessing; therefore, problems associated with waste transportation must be solved to assure the long-range viability of the nuclear power industry in this country. OWI authorized the Pilot Plant Section of the Chemical Technology Division at the Oak Ridge National Laboratory to conduct a survey of the existing transportation system for radioactive materials in order ( 1 ) to identify current and potential problems, and (2) to develop a comprehensive program plan that will ensure the availability of a transport system in 1985 
capable of moving commercial radioactive waste to federal repositories. The ovcrall Transportation/Logistics program has been designed to consider (1) spent fuel, (2) low-level TRU waste, (3) high-level waste, (4) intermediate-level waste, and (5) cladding hulls, with initial emphasis being placed on the first two types of waste.

As a part of the Transportation/Logistics program, several logistics models have been developed to study the movement of low-level TRU waste and spent fuel assemblies. The term logistics refers to a plan or program for moving waste from gencrating sites to disposal facilities. The logistics models include all aspects of waste transport and the operation of the disposal facilities. The logistics models are designed to determine the most economic waste shipping policies from a set of generating sites to a set of intermediate and final destinations. A number of operational cunstraints have been included in each model to reflect realistic nperation of shipping and receiving facilities. As more detailed information becomes available, the logistirs models will also be used to help manage the waste tiansportation systems and repository operation. The Low-Level TRU Waste Logistics model is described in Sect. 2, and the Spent Fuel Logistics model is describcd in Sect. 3. An additional model, the Spent Fuel Shipment Program, which is designed to prepare some of the input data for the Spent Fuel Logistics model, is discussed in Sect. 4.

The mathematical technique used to calculate the optimum shipping schedules in the logistics models is known as linear programming. Linear programming has been developed for determining the optimum allocation of resources (such as capital, raw materials, manpower, plant or other facilities) to obtain a particular objective when there are alternative uses for the resources. This technique is designed to solve a special type of problem-one in which all relations among the variables are linear in both the constraints and the functions to be optimized. Many physical systems can be adequately simulated using this technique. Linear programming has been applied extensively to transportation problems.

Linear programming operates simultaneously on all of the independent variables for the entire system and determines a system or global optimum. The program examines costs in all of the years during the study period to obtain a minimum overall cost (i.e., it may adjust some of the actions showing a higher cost in some years in order to take advantage of a system characteristic in other years of the study - hence, a lower overall cost). Other optimization techniques work on a year-by-year basis where the transportation costs are minimized for each year of the study. These techniques are time independent and cannot factor in constraints which cover several time steps or consider the interaction between different parts of the stidy. A year-by-year approach cannot guarantee a global or overall optimum. The only way to guarantee a global optimum is to optimize the entire system. Total system costs determined by linear programming represent lite absolutc minimum obtainable for a particular logistics problem. Any othcr shipping scliedule satisfying the problem constraints would result in a higher cost. .

Determining an optimized shipping schedule subject to a given set of constraints is only part of a logistics study. It is frequently necessary to cvaluate the sensitivity of the solution to perturbations of the original system cost and/or constraints. The linear programming technique is designed to perform sensitivity analysis with very little extra computations. It is not necessary to reformulate the problem and to repeat all of the calculations to evaluate the effects of changes in operating constraints or economic parameters. In addition to the items discussed above, the linear programming formulation can easily be modified to incorporate additional constraints. 


\section{LOW-LEVEL WASTE LOGISTICS MODEL}

The Low-Level Waste Logistics model is a mathematical formulation for solving classic transportation problems. A general description of the model is given in Sect. 2.1. The mathematical formulation is presented in Sect. 2.2. Sections 2.3 and 2.4 discuss data requirements of the program and the organization of results and output data respectively. $A$ sample problem is included in Sect. 2.5.

\subsection{General Description}

The Low-Level Logistics model has been developed to determine an optimum transportation policy for shipping low-level TRU contaminated wastes (LLT) from a set of generating sites to a set of federal repositories. Low-level wastes are generated in all portions of the nuclear fuel cycle. A portion of these wastes will have such a low level of contamination that they may be sent safely to commercial burial sites. However, a significant fraction of the wastes will be classified as TRU wastes and must be transported to a federal repository for final disposal.

As several federal repositories become operational, LLT waste generators will have a choice of destinations for waste shipments. Each generalor would prefer to minimize his total shipping and disposal costs by transporting them to the nearest repository, and many waste generators will be desiring to use the same disposal facility. As long as the waste processing capacity of a repository is capable of handling the demand for its services, the logistics of transportation are very simple. However, when the demand exceeds the processing capability of one or more of the repositories, some of the generators will be forced to utilize more expensive shipping alternatives. The resulting logistics problem becomes more complicated, and the entire LLT transportation system needs to be studied in order to minimize the waste disposal costs for the entire nuclear industry.

A computer program has been written to solve transportation logistics problems using the linear programming technique and was tested by applying it to the logistics of transporting low-level wastes. The program is designed to determine the most economical plan for moving the waste from cach getierator to the disposal facilities. Each generating site is assumed to be able to ship to any of the available repositories. The following constraints have been added to reflect repository operation:

(1) maximum annual waste processing capacity,

(2) minimum annual waste processing requirements, and

(3) ultimate storage capacity of the repositories. 
The Low-Level Waste Logistics model is a general model for evaluating shipping policies when a commodity is shipped directly from its source to the final destination without any intermediate stops. Applications of this model are not limited to the shipment of low-level radioactive wastes but can also be applied to any commodity that would be shipped within the constraints noted (e.g., the shipments of non-TRU low-level waste from generating sites to commerial burial grounds). The only limitation model is the inability of considering intermediate stops and subsequent transhipments to the final destinations. With a minor amount of reprogramming to include an additional repository constraint, this model could be used to determine optimum shipping polices for high-level waste, intermediate-level waste, and cladding hulls. These wastes will share common handling facilities at a repository. In order to determine the optimal logistics for the shielded wastes, the three types of waste need to be considered simultaneously. Preliminary calculations where the shielded wastes are considered individually are within the scope of the low-level logistıcs model.

A number of problems can be studied with the model to determine the impact various operating conditions or planning decisions would have on total system cust. The aspects that could be studied include:

(1) opening or closing specific repositories,

(2) alternating modes of transportation (e.g., rail vs truck),

(3) varying repository location,

(4) restricting or eliminating shipments in specific states or localities,

(5) distributing work loads between repositories,

(6) enlarging specific repositories,

(7) changing waste shipping forecasts,

(8) compacting of wastes,

(9) segregating non-contaminated wastes prior to shipment, and

(10) changing the radiological limit for classification as TRU waste.

The low-level waste logistics model was developed to determine a shipping schedule that would minimize transportation cost. Other criteria may be utilized to determine an optimum policy (e.g., minimize radiation exposure to the public, maximize utilization of transportation equipment, etc.).

\subsection{Mathematical Model}

A lincar programming approuth is the basis of the mathematical model. The quantities of waste being shipped are the independent variables or activities in the optimization calculations. The notation $S_{i j k}$ will be used to represent the amount of waste being shipped from generator $i$ to repository $\mathrm{j}$ in year $\mathrm{k}$.

An objective function, such as system transportation costs, is used to measure the relative performance of a particular set of activities $\left(S_{i j k}\right)$. The program is designed to select a set of non-negative activities which will minimize the objective function and at the same time satisfy any constraints imposed on the system. The objective function can be expressed as

$$
L=\sum_{i j k} \sum_{j k} c_{i j k} S_{i j k},
$$


where
$\mathrm{L}=$ value of objective function,
$\mathrm{c}_{i j k}=$ cost of transporting waste from site $\mathrm{i}$ to site $\mathrm{j}$ in year $\mathrm{k}$, and
$\mathrm{S}_{i j k}=$ amount of waste shipped from site $\mathrm{i}$ to site $\mathrm{j}$ in year $\mathrm{k}$.

All real systems are constrained by various physical limitations that restrict the allowable set of values for the activities. The optional solution must satisfy all constraints. It is conceivable that a set of inconsistent constraints could be defined such that a solution does not exist. This is known as an infeasible problem, and the code will identify such a case if it should arise. The constraints incorporated into the low-level waste logistics model are listed below.

(1) A specified amount of waste must be shipped annually from each generation site:

$$
\sum_{j} S_{i j k}=P_{i k} \quad \begin{aligned}
& i=1,2, \ldots, I \\
& k=1,2, \ldots, k,
\end{aligned}
$$

where

$\mathrm{P}_{i k}=$ amount of waste generated at site $\mathrm{i}$ in year $\mathrm{k}$.

(2) The amount of waste received at a repository in a given year must not exceed its maximum annual processing capacity:

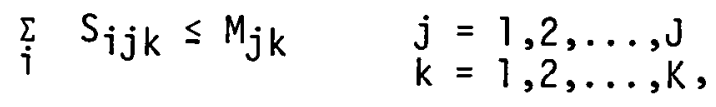

where

$\mathbf{M}_{j k}=$ maximum waste proccssing capacity at repository $\mathrm{j}$ in year $\mathrm{k}$.

(3) Each repository must receive a minimum amount of waste each year:

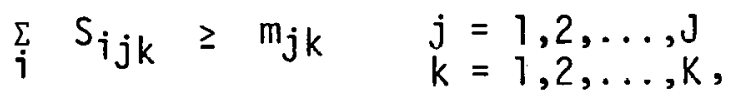

where

$\mathrm{m}_{j k}=$ minimum receiving rate for repository $\mathrm{j}$ in year $\mathrm{k}$.

(4) Each repository has a finite storage capacity:

$$
\sum_{k} \sum_{i} S_{i j k} \leq T_{j} \quad j=1,2, \ldots, j,
$$


where

$\mathrm{T}_{j}=$ ultimate storage capacity of repository $\mathrm{j}$.

The program is sized to handle 15 generating sites, 10 repositories, and a 30-year study period.

\subsection{Data Requirements}

The Low-Level Logistics mudel is a generalized program and includes a set of broad constrainte to reflert realistic operating conditions. However, when the mudel is used to study specific problems, additional operating constraints may be needed. Changing the constralnts will also alter the type and amount of input information requircd. The purpose of this section is to present a general overview of the information needed to define (1) the problem size, (2) the physical limitations or constraints of the system, and (3) the basic economic data.

The problem size is specified by the number of generating sites, the number of repositories, and the number of years in the study horizon. The following dimensions have been placed on these parameters: (1) 15 generating sites, (2) 10 repositories, and (3) 30-year planning horizon. These particular dimensions were chosen for convenience and typically would cover most of the logistics problems encountered. The dimensions could easily be expanded with a minor amount of reprogramming. The model will automatically reduce the size of the program to handle smaller problems. The problem size determines the amount of data required to completely specify the constraints of the system.

The following physical constraints need to be defined:

(1) annual waste volume or number of packages to be shipped from each generating site;

(2) maximum annual waste processing rate for each repository;

(3) minimum annual waste processing rate for each repository; and,

(4) the ultimate storage capacity for each repository.

The amount of waste shipped annually from each generating site must be defined. The amounts specified can vary from year to year and also can be set to zero if no wastes are to be shipped in a given year. Any convenient set of unitc can be uṣed for the wasste projections (e.g. tons, cubic uneters, rail car loads, elc). The uaer is required to define all input data in a consistent set of units. If the waste projections are given in cubic meters, the units for waste processing rates, elc., must also be in units of cubic meters, and cost information must have units of $\$ /$ cubic meter.

The maximum annual waste processing rate must be defined for each repository each year of the study. This data may vary from year to year to reflect changing waste processing capacity. Startup dates of a repository can be represented by setting the maximum waste 
processing rate to zero for the years prior to the beginning of commercial operation. For the remaining years, the actual processing capacity is used.

All data must be checked for consistency. For example, the sum of the maximum waste processing rates for all of the repositories must be equal to or larger than the total amount of waste to be shipped from all of the generating sites for that particular year.

Minimum annual waste processing rates may also be defined. If the minimum processing rates for each repository for each year of the study are zero, this information should be omitted from the input data. The basic structure of the linear programming algorithm automatically defines the minimum rates to be greater than or equal to zero, since all of the activities must be greater than or equal to zero. The final constraint which needs to be defined is the ultimate storage capacity for each repository.

In order to determine the optimal destinations of shipped waste, the total transportation costs from each generating site to each repository are needed. The total costs are composed of several basic costs, each of which are defined separately, and include waste loading, waste unloading, shipping, and repository disposal costs. The program sums the costs to arrive at a total cost for use in the optimization calculations. Any of the costs can be changed in any year of the study. All costs must have units (e.g., dollars per unit of waste) compatible with the units of the waste projections. The program is based on the assumption that any generating site can ship to any repository. If it is desired to block one or more of the transportation links (e.g., a path from a particular source to a particular destination), an extremely large shipping cost (e.g., $\$ 10^{6}$ per unit of waste) should be assigned to those links. These links will be economically unattractive when the optimization calculations are performed and would therefore not be utilized.

\subsection{Organization of Output}

A special subprogram has been written to summarize the input data and the results of the optimization calculations in a series of tables. (See Sect. 2.5, Sample Problem)

The first table lists the projected waste shipments from each generating site for each year of the study. The various costs for transporting wastes from each generating site to each repository are summarized with a separate table for each of the following activities: loading, unloading, shipping, and repository disposal. The total transportation costs are summarized in a separate table, and maximum annual storage limits for each repository are tabulated. The final table of input data includes the identification of the generating sites and repositories.

The results of the optimization calculations are summarized in a series of tables. The first set shows the sources of all waste shipped to each repository and the total amount of waste received each year at each repository. A separate table is prepared for each repository. The same information is tabulated showing the destinations of all waste shipped from each generating site along with the total shipments from this site each year. Again, a separate table is prepared for each generating site.

Additional tables are included showing the total amounts of wastes received annually and the cumulative receipts on a yearly basis for each repository. The annual shipping cost of transporting wastes to a repository is listed for each generating site. Another table indicates the conversions of the annual cost from total dollars to dollars per unit of waste for each generating site. 
From the shippers standpoint, the transportation costs would be minimized by shipping all wastes via the route of minimum cost. Typically, these shipments would be sent to the nearest repository. However, due to processing constraints, some of these repositories, though geographically near the generating site, may not be able to handle sufficient quantities of wastes to accommodate all potential shippers. In these special cases, some of the shippers will be required to transport a fraction or all of their wastes to alternate repositories, thus incurring additional costs. This further expense caused by system constraints are reported for each generating site in the final table.

\subsection{Sample Problem}

In order to test the Low-Level Waste Logistics model, a sample problem was formulated considering 12 generating sites and 6 repositories. A study horizon of 28 years was selected covering the years 1983 to 2010 . This problem is intended to demonstrate the utility of the logistics model, and the selected data are not intended to represent any specific set of waste projections, waste repositories, or actual transportation costs.

The amounts of wastes being shipped annually from each generating site are listed in Table 2.1. Transportation costs from each generating site to each repository are listed in Table 2.2. Only two repositories are available during the first four years (1983-1986) of the study. Three more repositories are opened in 1986, and the sixth repository is able to receive waste in 1989. The maximum waste processing rates of each repository varies during the first 8 years of operation and then remains constant over the remainder of the study period. Table 2.3 shows the maximum annual storage limits for each repository. No minimum receiving rates were included for any repository and were understood to be zero by the program.

The optimum waste shipping policy was evaluated by minimizing the total transportation costs over the study period. The results are shown in Tables 2.4 to 2.10 . Since only repositories 1 and 2 are open during the first four years, all wastes are shipped to these repositories. The waste-shipment patterns shift somewhat in 1987 when three more repositories become available. With the particular set of transportation costs assumed for this problem, the newly opened repositories only receive waste from a single generating site (i.e., repository 3 from souce 7 , repository 4 from source 10 , and repository 5 from source 8 ). The remaining souces continue to ship their wastes to repositories 1 and 2 until 1989 when repository 6 becomes ready for operation. Repository 6 is favorably situated and receives waste at its maximum processing rate during its first 5 years of operation. Many of the generating sites gradually divert their shipments from repositories 1 and 2 to repository 6. In fact, no waste is received at repository 2 for 9 years (1994-2002). In the later years of the study, the waste generation rates increase to the point where the maximum processing rates of several repositories is reached; repository 6 in 2003, repository 2 in 2006, repository 1 in 2008, and repository 5 in 2010. When the demand for waste storage at a given repository exceeds its capabiltiy of handling the wastes, shipments are then diverted to other repositories. For most problems, it is not readily apparent which shipments should be diverted. It is not necessarily the highest cost shipment to the repository but rather the shipment whose diversion cost is less than the incremental cost of diverting other shipments. The linear programming algorithm simultaneosly considers all activities over the entire study period in order to determine a minimum cost for the system rather than attempt a year-by-year minimization. 
Table 2.1. Annual shipments of TRU wastes from each generation source.

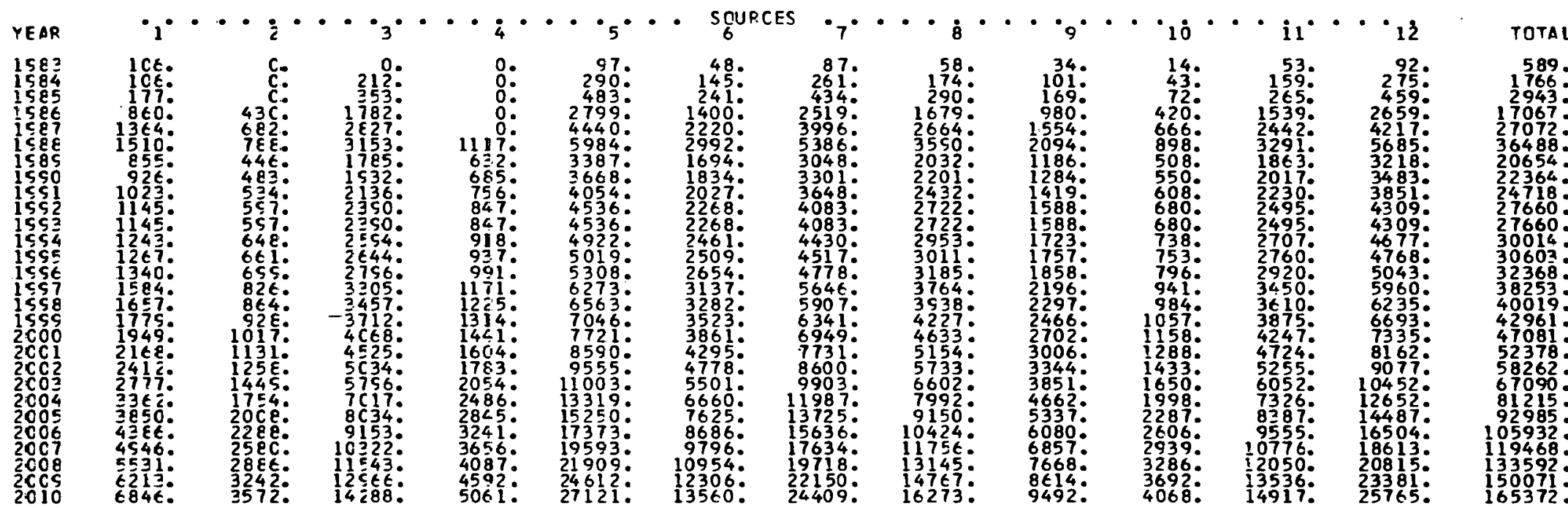


Table 2.2. Transportation costs for shipping TRU waste from generating site to repository.

\begin{tabular}{|c|c|c|c|c|c|c|c|c|c|c|c|c|}
\hline REFOS & 1 & 2 & 2 & 4 & ${ }^{\circ} 5^{\circ}$ & 6 & $7^{7}$ & 8 & 9 & 10 & il & 12 \\
\hline $\begin{array}{l}1 \\
2 \\
3 \\
4 \\
5 \\
6\end{array}$ & $\begin{array}{r}15.56 \\
33: 73 \\
39: 25 \\
41: 04 \\
37: 08 \\
5: 85\end{array}$ & $\begin{array}{l}19: 1: \\
24: 60 \\
25: c 1 \\
32: c 1 \\
25: c 9 \\
23: t !\end{array}$ & $\begin{array}{l}2 E .6 c \\
2 E: 06 \\
4=11 \\
3 \epsilon: 74 \\
36: 80 \\
21.53\end{array}$ & $\begin{array}{l}20.48 \\
23: 42 \\
39: 34 \\
35.84 \\
31: 67 \\
22.57\end{array}$ & $\begin{array}{l}27: 09 \\
29: 91 \\
45: 22 \\
41: 21 \\
38: 79 \\
16: 55\end{array}$ & $\begin{array}{l}20.50 \\
20: 95 \\
29: 91 \\
28: 50 \\
23: 06 \\
24: 45\end{array}$ & $\begin{array}{l}44.88 \\
48: 48 \\
27: 31 \\
38: 55 \\
38: 35 \\
49.70\end{array}$ & $\begin{array}{l}31.88 \\
17.08 \\
26: 95 \\
16: 76 \\
13.57 \\
34.16\end{array}$ & $\begin{array}{r}13.50 \\
32.62 \\
38.56 \\
39: 65 \\
34.511 \\
6.76\end{array}$ & $\begin{array}{l}49.54 \\
40: 53 \\
31: 55 \\
37: 05 \\
31: 55 \\
51.86\end{array}$ & $\begin{array}{l}25.38 \\
24: 45 \\
43.14 \\
38: 17 \\
37.89 \\
19.98\end{array}$ & $\begin{array}{r}22: 97 \\
31: 97 \\
42: 87 \\
42: 55 \\
38: 38 \\
7: 55\end{array}$ \\
\hline
\end{tabular}


Table 2.3. Maximum annual TRU waste storage limits at repositories.

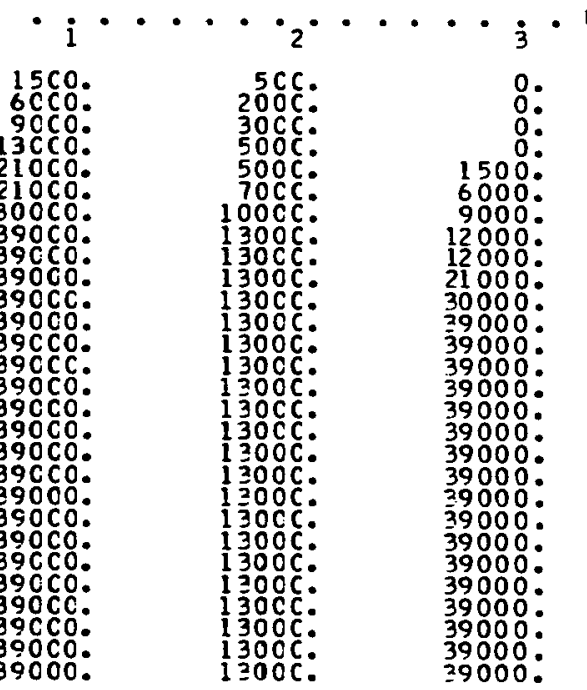

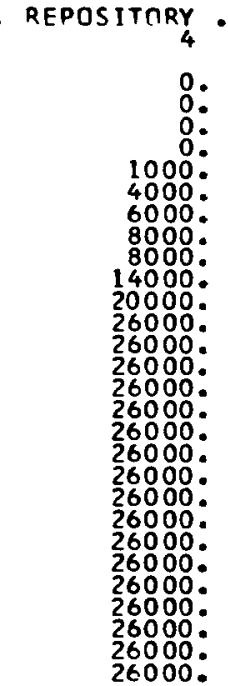
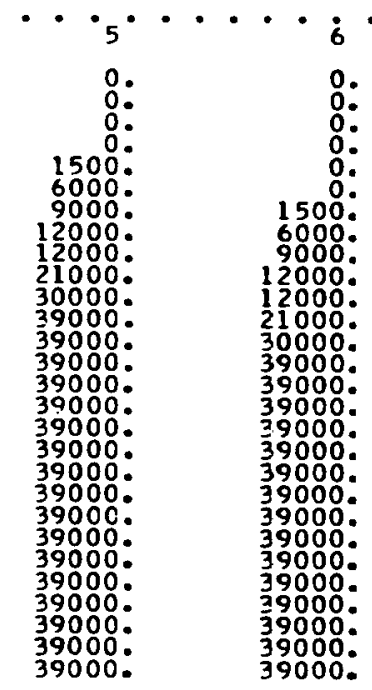

TDTAL

983
984
985
986
987
988
985
990
991
992
994
995
996
997
998
9000
2001
2002
2003
2004
2005
2004
2007
2008
2010
( 
Table 2.4. TRU waste received at repository No. 7 from individual generating sites.

\begin{tabular}{|c|c|c|c|c|c|c|c|c|c|c|c|c|c|}
\hline YEAR & $1^{\circ}$ & 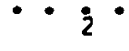 & $3^{\circ}$ & 4 & $5^{\circ}$ & - 6 & $7^{\circ}$ & $\dot{8}^{\circ}$ & $\because 9^{\circ}$ & $10^{\circ}$ & il & 12 & TOTAL \\
\hline 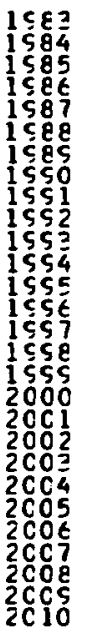 & 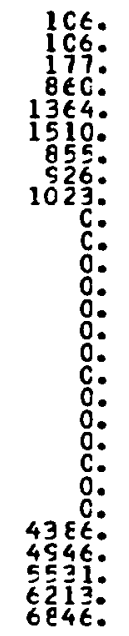 & 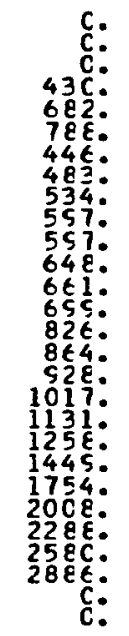 & $\begin{array}{l}0 . \\
0: \\
0: \\
0: \\
0: \\
0: \\
0: \\
0: \\
0: \\
0: \\
0: \\
0: \\
0: \\
0: \\
0: \\
0: \\
0: \\
0: \\
0: \\
0: \\
0: \\
0:\end{array}$ & 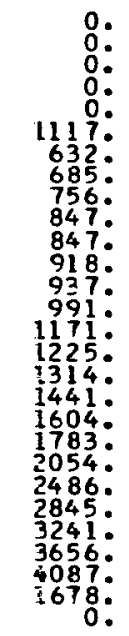 & 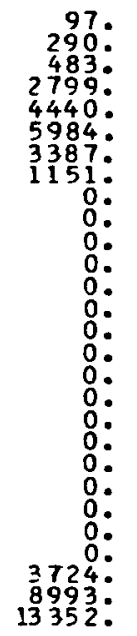 & 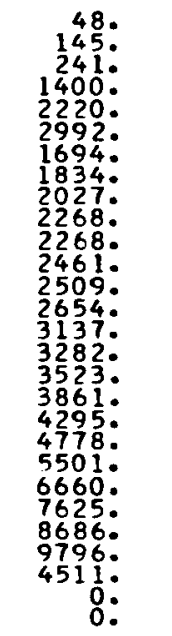 & 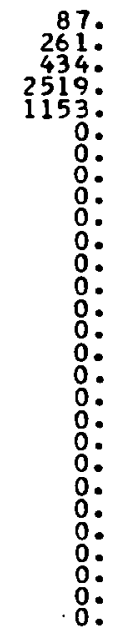 & 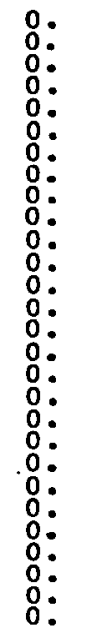 & 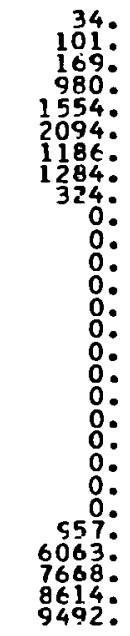 & $\begin{array}{l}0: \\
0: \\
0: \\
0: \\
0: \\
0: \\
0: \\
0: \\
0: \\
8: \\
0: \\
0: \\
0: \\
0: \\
0: \\
0: \\
0: \\
0: \\
0:\end{array}$ & $\begin{array}{r}0 . \\
0: \\
420: \\
2442: \\
00: \\
00: \\
00: \\
00: \\
00: \\
00: \\
00: \\
00: \\
00: \\
00: \\
00: \\
3345: \\
5708: \\
8098: \\
10593: \\
13502: \\
93100\end{array}$ & 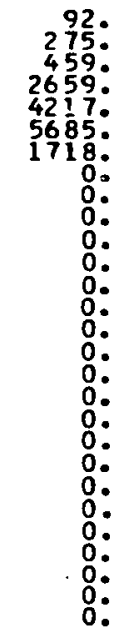 & 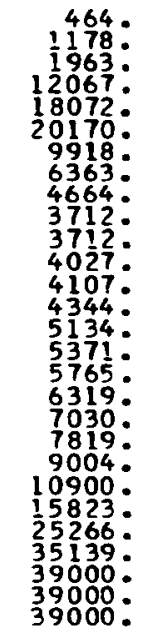 \\
\hline TCTAL & 34845. & 25554. & 0. & $3 c 315$. & 44700 & 90416 & 4454 . & 0. & 40520 & 0. & 53418. & 15105. & 345330 . \\
\hline
\end{tabular}


Table 2.5. TRU waste received at repository No. 2 from individual generating sites.
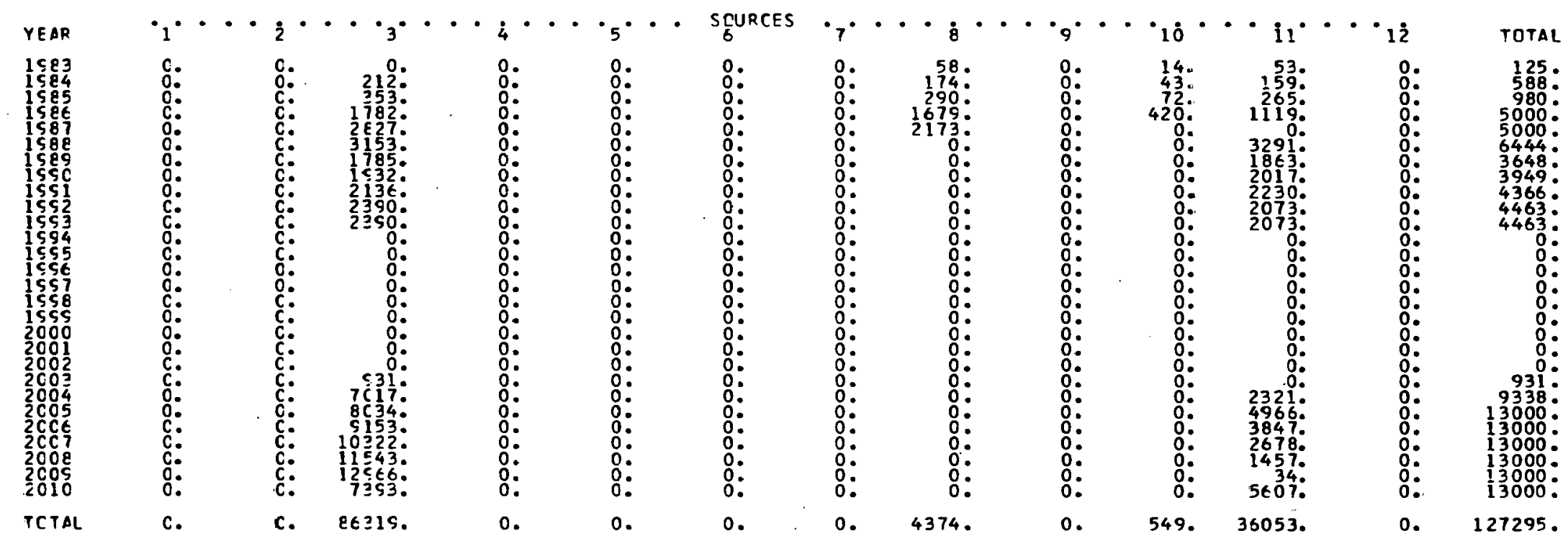
Table 2.6. TRU waste received at repository No. 3 from individia ' generating sites.
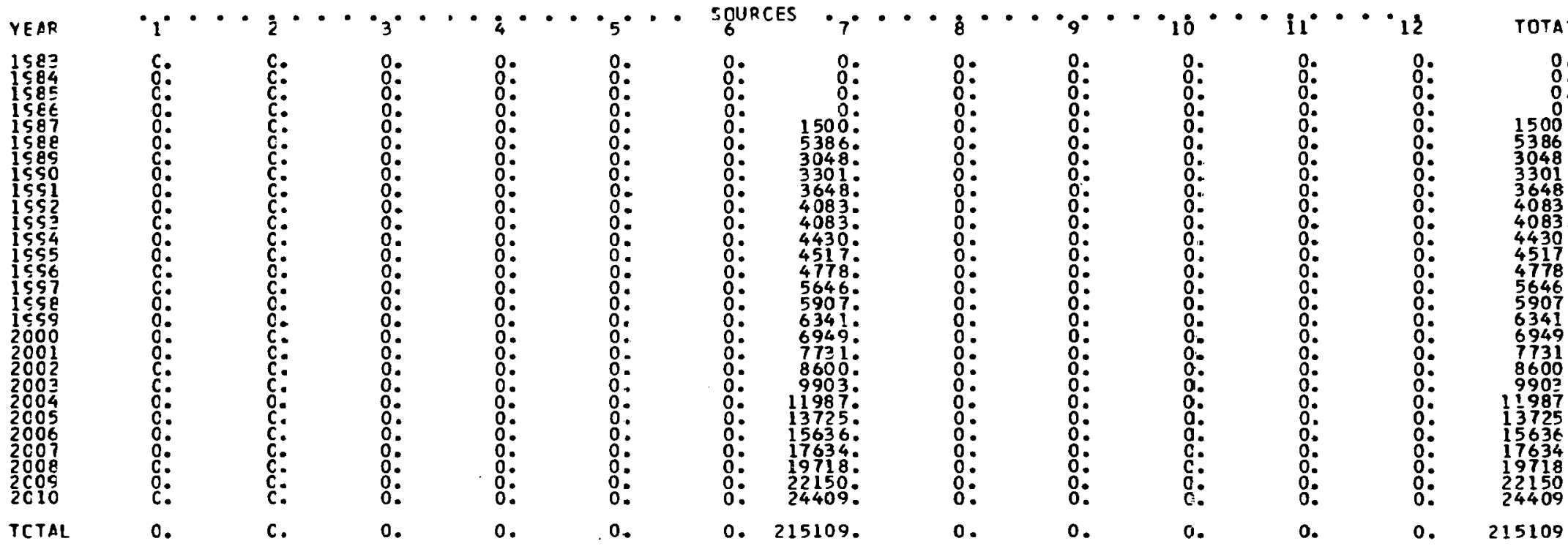

OTAL

0.

c.

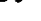

0. 
Table 2.7. TRU waste received at repository No. 4 from individual generating sites.
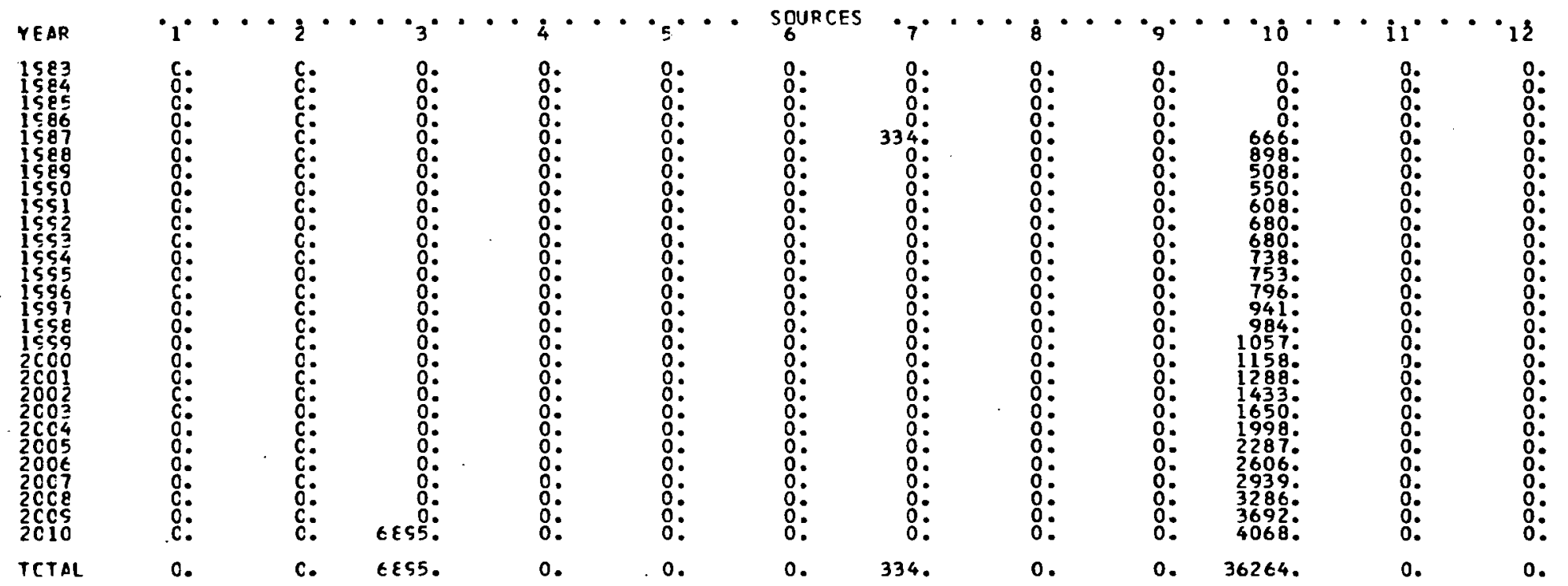

TOTAL

0.
0

$1000:$

508

680 :

$738:$

941 .

1057 .

1288.

1650.

$2287:$

2939.

10962 :

43493. 
Table 2.8. TRU waste received at repository No. 5 from individual generating sites.
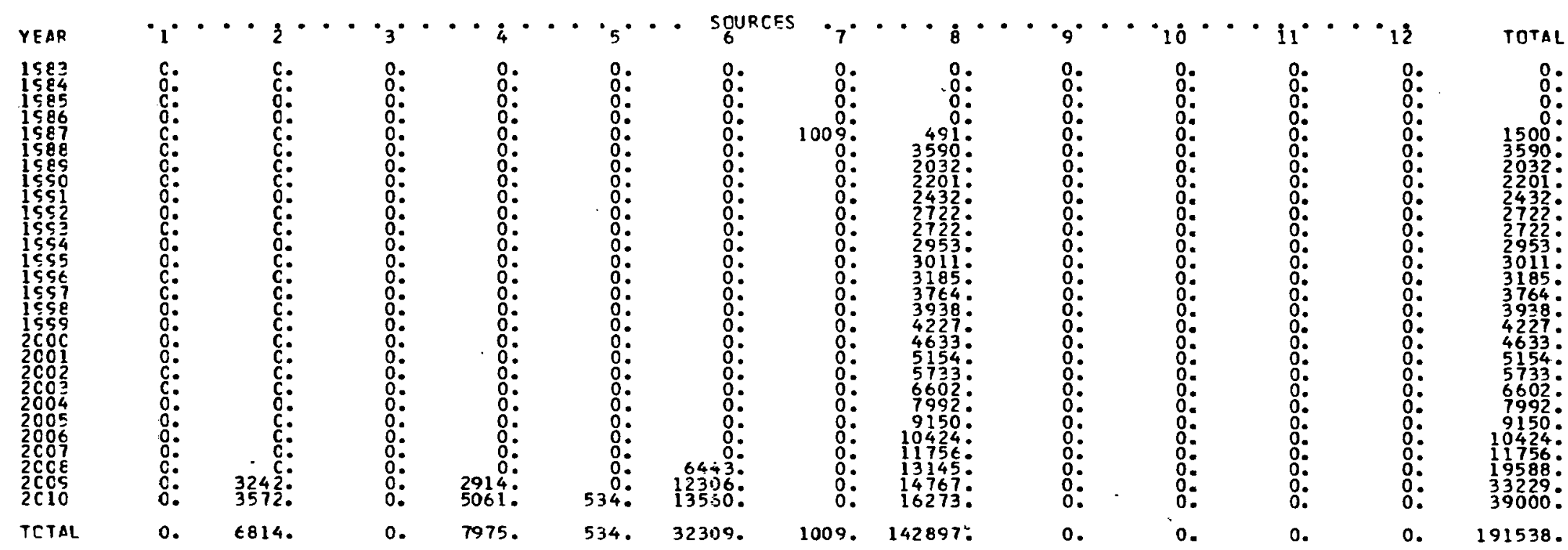
Table 2.9. TRU waste received at repository No. 6 from individual generating sites.

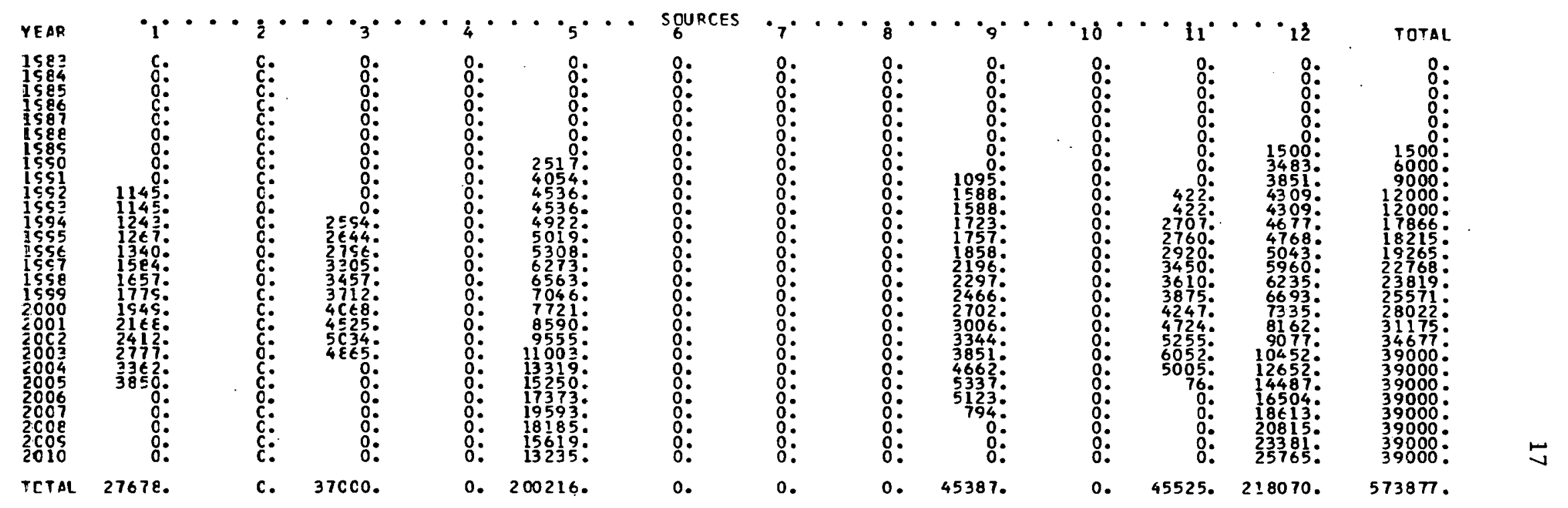


Table 2.10. Total amount of TRU waste received at repositories.

YEAR $\left.{ }_{i} \cdots \cdots_{2} \cdots \cdots\right]_{3}$

1983

1985

1987

1990

1992

1994
1995
1996

1996

1998

2000

2002

2004

2006

2008

2005

TOTAL
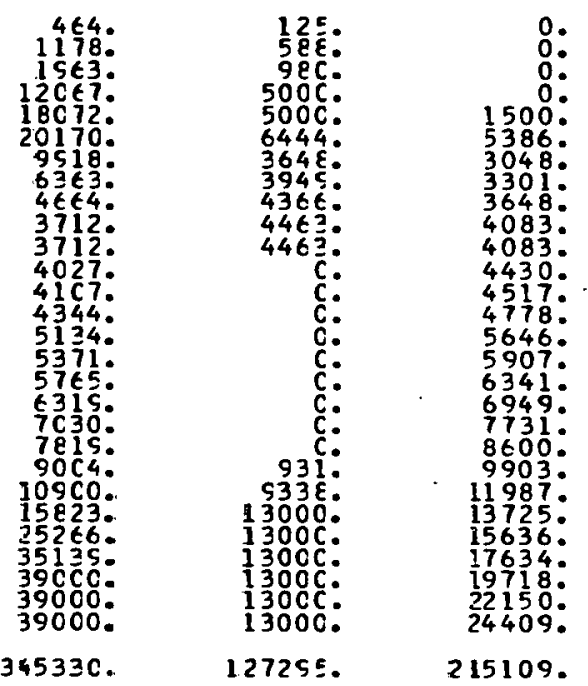

- REPOSITORY

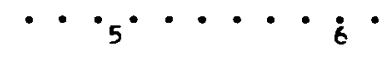

TOTAL
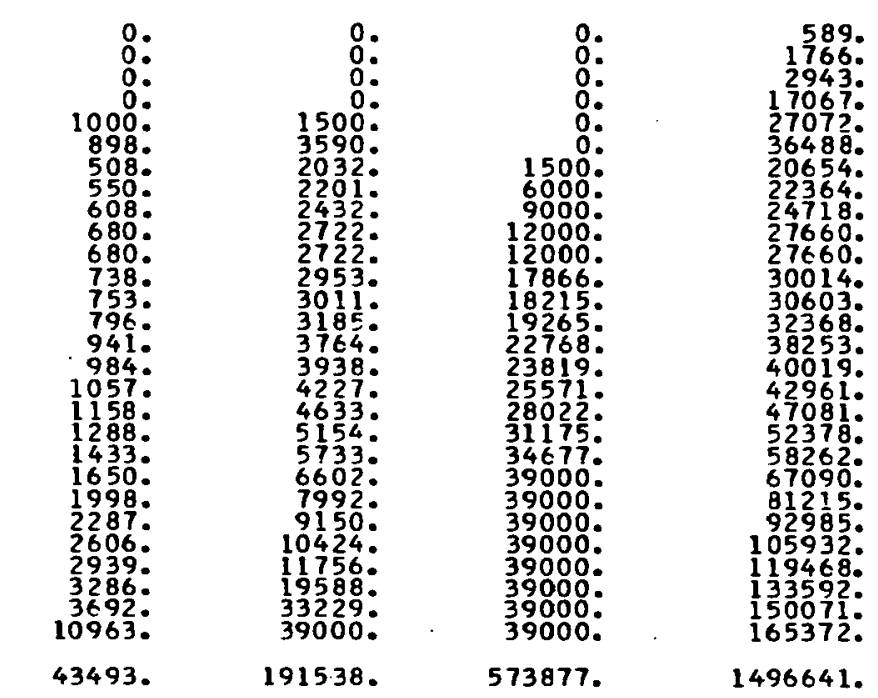
The annual waste shipping cost is listed for each generating site in Table 2.11. The additional costs incurred by each generating site that is required to transport wastes beyond the nearest to an alternate repository are shown in Table 2.12. If all repositories had an infinite annual processing rate and an infinite storage capacity, none of the generating sites would incur any additional costs. However, all waste disposal facilities have finite limits, and the possibility exists that one or more of the generating sites will have to ship waste to a repository which might be its second or third choice. The diversion of shipments can be caused by two factors. If the annual handling capability of a repository is exceeded, short-term diversion will occur. As a repository approaches its ultimate storage capacity, shipments from some generating sites will be diverted to allow space for the shippers with higher diversion costs. The program schedules waste shipments to minimize the cost for the entire waste transport system.

The total system cost shown in Table 2.11 represents the absolute minimum obtainable for the particular problem. This value is derived by considering all shipments over the entire study period. Any other shipping schedule satisfying the problem constraints would result in a higher total cost.

\section{SPENT FUEL LOGISTICS MODEL}

The Spent Fuel Logistics model is a mathematical formulation for solving transportation problems with intermediate storage and subsequent transhipments to a final destination. A general description of the model is given in Sect. 3.1. The mathematical formulation is presented in Sect. 3.2. Sections 3.3 and 3.4 discuss data requirements of the program and the organization of results respectively. A sample problem is included in Sect. 3.5.

\subsection{Gencral Description}

The Spent Fuel Logistics model has been developed to determine an optimum transportation policy for shipping spent fuel from nuclear power plants to an away-from-reductur slorage facility (AFR) and the subsequent shipments from the AFR to a federal repository. All nuclear reactors are refueled periodically, generally once a year. The fuel assemblies removed are initially stored at the reactor in a spent fuel storage pool. After a suitable cooling period, the spent fuel will be shipped to a reprocessing facility or an away-from-reactor storage facility, or geologic repository. For the once-through fuel cycle concept, none of the discharged spent fuel would be reprocessed to recover unburned fuel. Instead, all spent fuel would be stored in one of several AFR's situated around the country. After residing in an AFR for a period of years (typically 5 to 10 years), the spent fuel will be shipped to a federal repository for longer-term storage and/or disposal.

When several AFR facilities become operational, the utilities will have a choice of destinations for spent fuel shipments. Each utility would prefer to minimize its total shipping and disposal costs. Since the government will probably take title to the spent fuel at the first government facility in the transportation chain, which would be the AFR facility, each utility would want to ship to the nearest AFR facility. However, when the total costs of moving spent fuel from the generating sites to the repository are considered, significant savings might be realized by having a utility ship fuel to another AFR facility rather than the closest one. 
Table 2.11. Annual TRU waste transportation costs $\left(\$ 10^{E}\right)$.

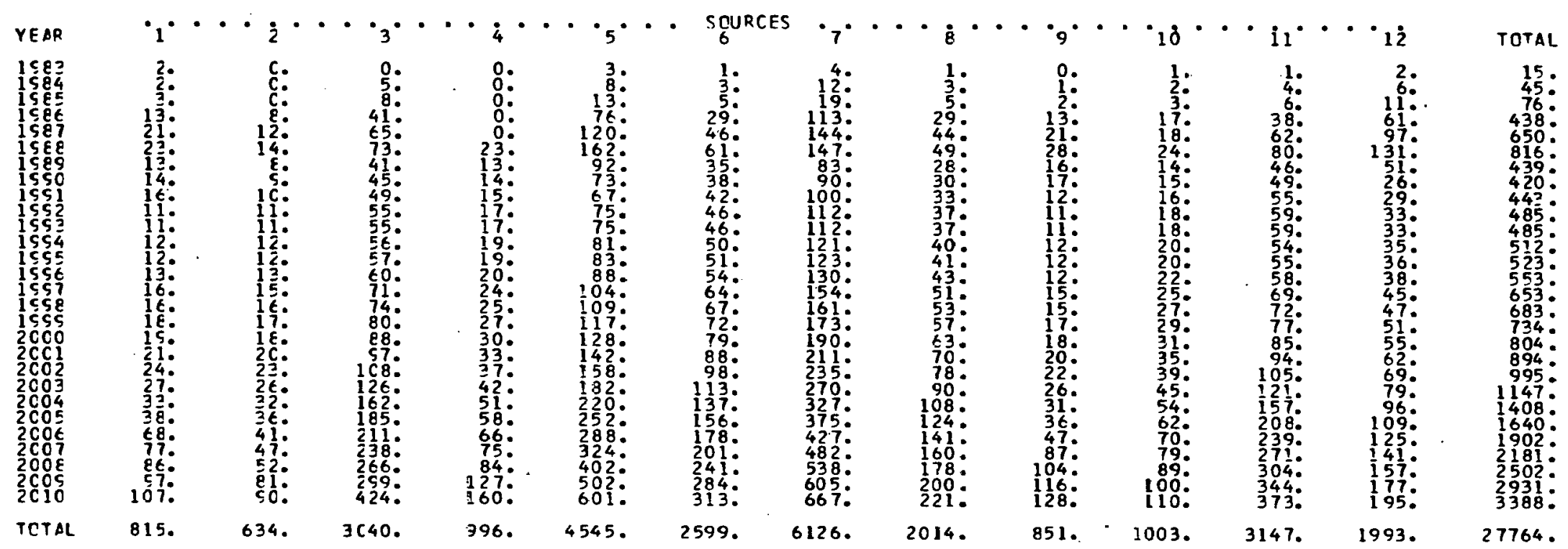


Table 2.12. Additional costs incurred by generating site by not shipping waste to nearest respository $\left(\$ 10^{6}\right)$.
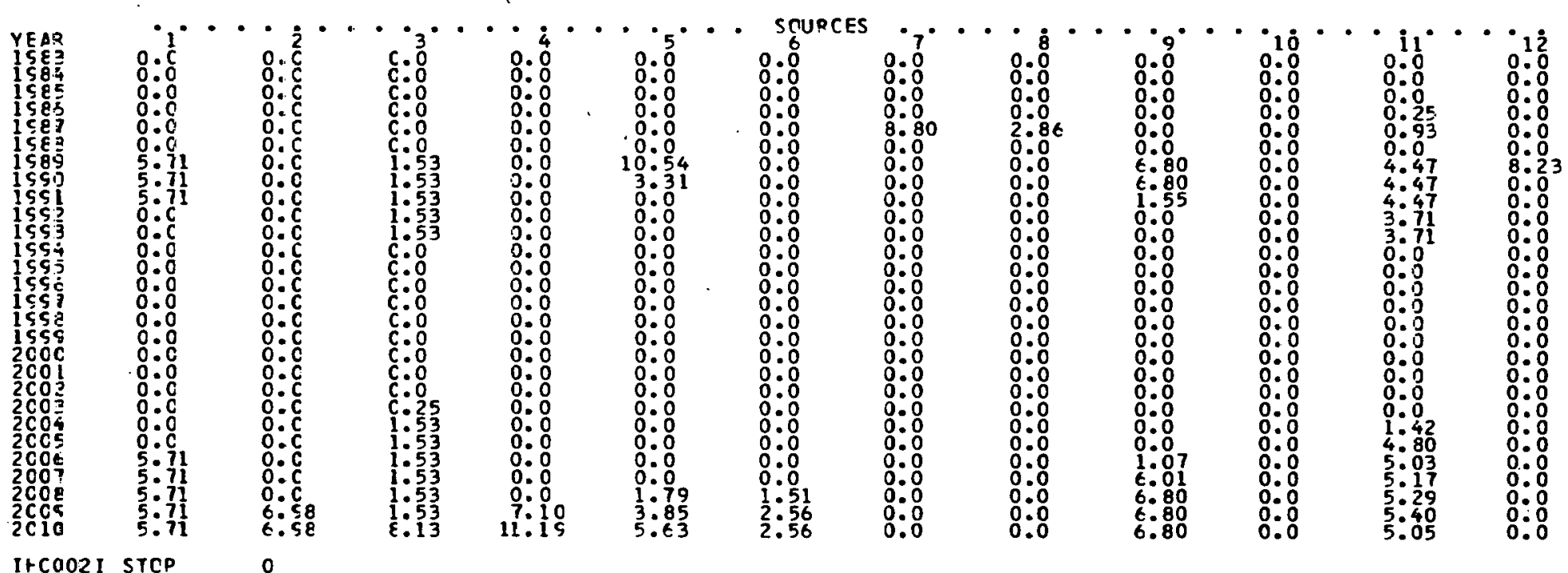

TOTAL

IrCOO2I STCP 
When the demand for storage exceeds the overall storage capacity of one or more of the AFR facilities, the resulting logistics problem becomes more complicated, and the entire spent fuel transportation system needs to be studied in order to minimize disposal costs for the entire nuclear industry.

A computer program, the Spent Fuel Logistics program, was developed to optimize the shipment of spent fuel from the reactors to AFR's and from AFR's to federal repositories. The program will determine the total costs of shipping spent fuel from the various reactors to a set of AFR's over an extended time period. While each reactor in the U.S. could be simulated, it is convenient to lump the reactors in a small geographic region into a single generating source. The program is dimensional to consider up to 30 separate generating sources, 5 AFR's, and 5 federal repositories. The program will also optimize the storage policies at both the generating sites and at the AFR's. Each of the generating sites is assumed to be able to ship to any of the AFR's which in turn can ship to any of the federal repositories. The Spent Fuel logistics model is flexible enough to consider direct shipments from a generating site to a repository bypassing the interim storage facilities. Hence, if desired, any generating site can ship fuel to any AFR or any repository. The following constraints and variable bounds have been included in the model to reflect generating site, AFR, and repository operation:

(1) storage capacity at generation sites,

(2) spent fuel handling capacity at AFR's,

(3) storage capacity at AFR's,

(4) minimum residence time of spent fuel at AFR's,

(5) spent fuel handling capacity at repositories, and

(6) ultimate storage capacity at repositories.

The Spent Fuel Logistics model is a general model for evaluating shipping policies when a commodity is shipped from its source to its final destination with the possibility of an intermediate stop. Applications of this model are not limited to the shipment of spent fuel but can also be applied to any commodity that would be shipped within the framework mentioned above. The only limitation of the model is its inability to consider more than one intermediate stop between source and destination.

A number of problems can be studied with the Spent Fuel Logistics model to evaluate the impact various operating conditions or planning decisions would have on total system cost. The aspects which could be studied include:

(1) opening or closing specified AFR facilities and/or repositories,

(2) alternating modes of transportation (rail vs truck),

(3) varying AFR or repository location,

(4) restricting or eliminating shipments across specific state lines,

(5) distributing work loads at AFR facilities and/or repositories,

(6) varying storage capacity at specific AFR facilities and/or repositories,

(7) changing the projected rate at which nuclear reactors come on line, and

(8) varying handling rates at AFR facilities and/or repositories.

Additionally, the Spent Fuel Logistics model would be particularly useful in evaluating proposed locations for AFR facilities and/or repositories which would minimize transportation costs, trip distances, cask fleet requirements, radiation exposure to workers and general population, etc. 


\subsection{Mathematical Model}

The linear programming approach was selected for both the mathematical model and all equations used to simulate the spent fuel transportation system are linear. The following four sets of independent variables or activities are required to describe the system:

(1) the amount of spent fuel being stored at generating site $i$ at the end of year $k$, $\mathrm{G}_{i k}$,

(2) the amount of spent fuel being shipped from generation site $i$ to AFR site $j$ in year $\mathrm{k}, \mathrm{X}_{i j k}$,

(3) the amount of spent fuel being stored at AFR site $j$ at the end of year $k, A_{j k}$, and

(4) the amount of spent fuel being shipped from AFR site $j$ to repository 1 in year $k, Y_{j l k}$.

An objective function, such as system transportation and storage costs, is used to measure the performance of a particular set of activities. The model is designed to select a set of non-negative activities which will minimize the objective functions while simultaneously satisfying any constraints imposed on the system. The objective functions can be expressed as

$$
\begin{aligned}
Z= & \sum_{j k} \sum_{k}\left(s_{i} G_{i k}\right)+\sum_{i} \sum_{j k} \sum_{k}\left(c_{i j k} X_{i j k}\right)+ \\
& \sum_{j k} \sum_{k}\left(d_{j k} A_{j k}\right)+\sum_{j} \sum_{\ell} \sum_{k}\left(q_{j \ell k} Y_{j \ell k}\right),
\end{aligned}
$$

where

$$
\begin{aligned}
\mathrm{Z} & =\text { value of objective function, } \\
\mathrm{s}_{i} & =\text { cost of storing spent fuel at generating site, } \\
\mathrm{c}_{i j k} & =\text { cost of shipping spent fuel from generating site to AFR, } \\
\mathrm{d}_{j k} & =\text { cost of storing spent fuel at AFR, and } \\
\mathrm{q}_{j l k} & =\text { cost of shipping spent fuel from AFR to repository. }
\end{aligned}
$$

All real systems are constrained by various physical limitations that restrict the allowable set of values for the activities. The optimal solution must satisfy all constraints.

The amount of spent fuel being stored at a generating site at the end of a year is cualculated by a material balance

$$
G_{i k}=G_{i k-1}+D_{i k}=\Sigma X_{i j k} \quad \begin{aligned}
& i=1,2, \ldots, I \\
& k=2,3, \ldots, k
\end{aligned}
$$

where

$D_{i k}=$ amount of spent fuel being discharged from the reactors at site $\mathrm{i}$ in year $\mathrm{k}$. 
For the first year of the study, Eq. (7) takes a special form

$$
G_{i 1}=G_{i 0}+D_{i 1}-\sum_{j} X_{i j 1} \quad i=1,2, \ldots, I,
$$

where

$$
\mathrm{G}_{i 0}=\text { amount of spent fuel being stored at reactor sites at start of study. }
$$

The amount of fuel being stored at the generating site is constrained to be within certain limits

$$
0 \leq G_{i k} \leq T_{i k} \quad \begin{aligned}
& i=1,2, \ldots, I \\
& k=1,2, \ldots, k
\end{aligned}
$$

where

$$
\mathrm{T}_{i k}=\text { storage capacity at generating site. }
$$

For some problems, it would be desirable to have each reactor ship all fuel added to its storage pool annually. This can be accomplished by defining all $T_{i k}$ to be equal to zero reducing Eq. (7) to

$$
\begin{aligned}
& \sum_{i j k} X_{i j k}=D_{i k} \quad \begin{array}{l}
i \\
k
\end{array} \quad 1,2, \ldots, I \\
& k=1,2, \ldots, k .
\end{aligned}
$$

The amount of spent fuel being stored at an AFR is also determined from a material balance

$$
A_{j k}=A_{j} k-1+\sum_{i} X_{i j k}-\sum_{\ell} Y_{j \ell k} \quad \begin{aligned}
j & =1,2, \ldots, J \\
k & =1,2, \ldots, k
\end{aligned}
$$

Again, for the first year of the study, $A_{j o}$ represents the amount of spent fuel stored at the AFR at the start of the study. The total amount of spent fuel stored in an AFR is also limited

$$
0 \leqq A_{j k} \leq Q_{j k} \quad \begin{aligned}
& j=1,2, \ldots, \mathrm{J} \\
& k=1,2, \ldots, k,
\end{aligned}
$$

where

$$
\mathrm{Q}_{j k}=\text { maximum storage capacity of AFR site } \mathrm{j} \text { in year } \mathrm{k} \text {. }
$$


The amount of spent fuel being handled at an AFR is limited by the number of casks which can be unloaded or loaded per year. The model assumes the same equipment is used to unload or to load a cask, hence the total receiving and shipping rate for each AFR is constrained as follows:

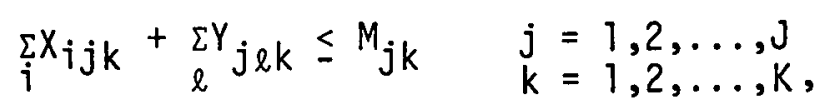

where

$$
\mathrm{M}_{j k}=\text { maximum spent fuel handling rate at } \mathrm{AFR} \text { site } \mathrm{j} \text { in year } \mathrm{k} \text {. }
$$

In some scenarios, all spent fuel received by an AFR must reside in that AFR for a maximum period of time (e.g., 10 years). These requirements introduce an additional series of constraints as follows:

$$
\sum_{\ell} \sum_{k=1}^{\theta} Y_{j \ell k} \leq \sum_{i k=1}^{\theta-\tau} X_{j j k} \quad \begin{aligned}
& j=1,2, \ldots, J \\
& \theta=\tau+1, \tau+2, \ldots, k .
\end{aligned}
$$

Equation (14) states that in a given year the total shipments of spent fuel from an AFR can not exceed the total amount received $\tau$ years previously. This constraint requires all fuel to remain at an AFR for at least $\tau$ years.

The operating characteristics of the repositories also introduce some constraints. The amount of spent fuel received at a repository is limited by the fuel handling capacity

$$
\begin{aligned}
& \sum_{j \ell k}<H_{l k} \quad \begin{array}{l}
\ell \\
k=1,2, \ldots, L \\
k
\end{array}=1,2, \ldots, K,
\end{aligned}
$$

where

$$
\mathrm{H}_{l k}=\text { maximum fuel handling capability of repository } \mathrm{l} \text { in year } \mathrm{k} \text {. }
$$

Each repository has a finite storage capacity over its life time. This is represented by

$$
\sum_{j} \sum_{k} Y_{j \ell k}<U_{\ell} \quad \ell=1,2, \ldots, L,
$$

where

$$
\mathrm{U}_{l}=\text { ultimate storage capacity of repository } \mathrm{l} \text {. }
$$




\subsection{Data Requirements}

The Spent Fuel Logistics model is a generalized program and includes a set of general constraints to represent realistic operation of AFR facilities, repositories, and transportation systems. When the model is used to study specific problems, the mathematical formulation may require additional constraints or modification of the existing constraints. The purpose of this section is to present an overview of the information needed to define the problem size, the physical limitations at both the AFR facilities and repositories, and the basic economic data.

The problem size is determined by the number of generating sites, the number of AFR facilities, the number of repositories, and the number of years in the study horizon. The following dimensions are currently being used for these variables:

(1) 30 generating sites,

(2) 5 AFR facilities,

(3) 5 repositories, and

(4) 25-year planning horizon.

The model will automatically reduce the size of the program in order to handle smaller problems. Larger problems could be considered with a minor amount of reprogramming.

To describe a generating site, the following information must be defined:

(1) the amount of spent fuel added to the storage pool annually,

(2) the maximum capacity of the spent fuel storge pool, and

(3) the amount of spent fuel already being stored at the start of the study horizon.

The model assumes that spent fuel can be stored at the generating site provided sufficient storage space is available. The program will then calculate when the spent fuel would be shipped to an AFR site. The maximum storage capacity can be varied from year to year. If the storage capacity is set equal to zero, all fuel added to the storage pool will be shipped to an AFR that year.

Specifying the amount of spent fuel added to the storage pools of each generating site for each year of the study requires a significant amount of data. The Spent Fuel Shipment Program (Sect. 4) is designed to provide this information.

To describe an AFR facility, the following information is required: maximum storage capacity, maximum spent fuel handling capability, and minimum storage time required at the AFR. The first two items must be defined for each AFR every year included in the study period and the values may vary from year to year. If a particular AFR is not available for storing spent fuel, the maximum handling capabiltiy must be set to zero.

All data must be checked for consistency. For example, the sum of the maximum handling capabilities at the AFR facilities must be equal to or larger than the total amount of spent fuel which must be shipped from all generating sites in a given year.

A repository is defined by specifying the maximum annual spent fuel processing rate and the ultimate storage capacity. Startup dates of a repository can be represented by setting the maximum processing rate to zero for the years prior to the beginning of commercial operation. For the remaining years, the actual processing capacity is used. 
In order to determine the optimal destinations of the shipped spent fuel, the total shipping costs for each of the transportation links are needed. The total costs are composed of several basic costs, each of which are defined separately. The basic costs include expenses incurred in waste loading, waste unloading, shipping (including cask rental and special train charges) and storage. The program sums the individual costs to arrive at a total figure for use in the optimization calculations. Any of the costs can be changed in any year of the study. All costs must have units compatible with the units of the spent fuel discharge (assemblies or metric tons of heavy metal).

Since there are three distinct shipments being considered, three sets of costs must be defined. The first set covers the shipment from the generating site to the AFR facility, the second set, the shipment from the AFR to the repository, and the third set for the direct shipment from a generating site to a repository. The program assumes any source can ship to any destination. If it is desired to block one or more of the transportation links, an extremely large shipping cost should be defined for those particular links. These links will be economically unattractive when the optimization calculations are performed and would not be utilized.

\subsection{Organization of Output}

A special subprogram has been written to summarize the input data and the results of the optimization calculations. An example of the program-generated information is included in Sect. 3.5, Sample Problem.

The first table lists the amount of spent fuel eligible for shipment from each generating site for each year of the study. The various costs for transporting spent fuel are summarized with a separate table for each cost item (e.g., loading, unloading, shipping, storage, and repository disposal). The total transportation costs are summarized in two separate tables: (1) one table for the movement of spent fuel from the generating sites to the AFR facilities and (2) a second table for the movement from AFR facilities to repositories. These costs and total transportation costs include freight charges, cask rental, and special train charges.

Additional tables are included showing total amounts of spent fuel received annually for the AFR facilities and the repositories. A table indicating the amount of spent fuel being stored at each AFR facility for each year of the study is also included.

The annual shipping cost of transporting spent fuel from the generating sites and from the AFR is also listed for each source of shipments. The storage cost incurred at the individual AFR's is also tabulated.

The total cost of transporting spent fuel over the study horizon is also tabulated. This table includes total cost of storage at generating sites prior to shipment, transportation cost of moving spent fuel from generating sites to AFR's, storage at AFR's, and shipment from AFR's to repositories.

\subsection{Sample Problem}

A study was performed for OWI to determine the feasibility of situating AFR facilities for storing spent fuel in various parts of the U.S. The actual selection of candidate sites for ArR facilities and geological repositories is still several years off and is subject to extensive review and evaluation by DOE, NRC, EPA, the affected local and state authorities, and the general 
public. However, a Transportation/Logistics study that attempts to estimate transportation costs associated with AFR facilities must be based on specific assumptions as to the location of the facilities. The following sites were selected for the AFR facilities for calculational purposes only:

(1) upper Midwest location - Morris, Ill.

(2) south Atlantic location - Barnwell, S.C.

(3) southeastern location - Oak Ridge, Tenn.

(4) northwestern location - West Valey, N.Y.

Geological investigations for a possible repository site are now being concentrated in six mlajur regions. For this sample problem, transportation costs were estimated for a single repository site-the interior Gulf Coast Salt Domes located at Minden, La.

A run was made using the Spent Fucl Logistics nodel to define the flow of spent fuel from the reactors to the four AFR facilities and the subsequent transhipment, to a repository. The basic assumptions for the study included the following:

(1) spent fuel discharge rates were to be based on an installed nuclear capacity projection of $380 \mathrm{GWe}$ in the year $200 \mathrm{O}_{3}^{\mathrm{C}}$

(2) beginning in 1982, all spent fuel will be delivered to the AFR facility or repository 5 years after reactor discharge, with the exception of the pre-1977 inventory, which will be delivered directly to the repository between 1991 and 1995;

(3) in the period 1982-1984, all spent fuel will be delivered to AFR storage facilities. Between 1985 and 1989, the repository will be capable of receiving shipments at the following limited rate, expressed in metric tons uranium (MTU) per year:

\begin{tabular}{cc} 
Year & MTU/year \\
\cline { 2 - 2 } 1985 & 500 \\
1986 & 700 \\
$1987-1989$ & 1000
\end{tabular}

Any $b$-yeál-old luel in excess of these amounts will be shipped to an AFR facility for storage;

(4) beginning in 1990, all spent fuel shipments will go directly to the repository. In 1991 , the $\Lambda F R$ facilities will starl to ship stored spent fuel to the repository. The combined shipping rates from all AFR facilities will be limited to $2000 \mathrm{MTU} /$ year. The amount of spent fuel being shipped annually to the AFR facilities and to the repository shown in Fig. 3.1. 
ORNL DWg 78-681

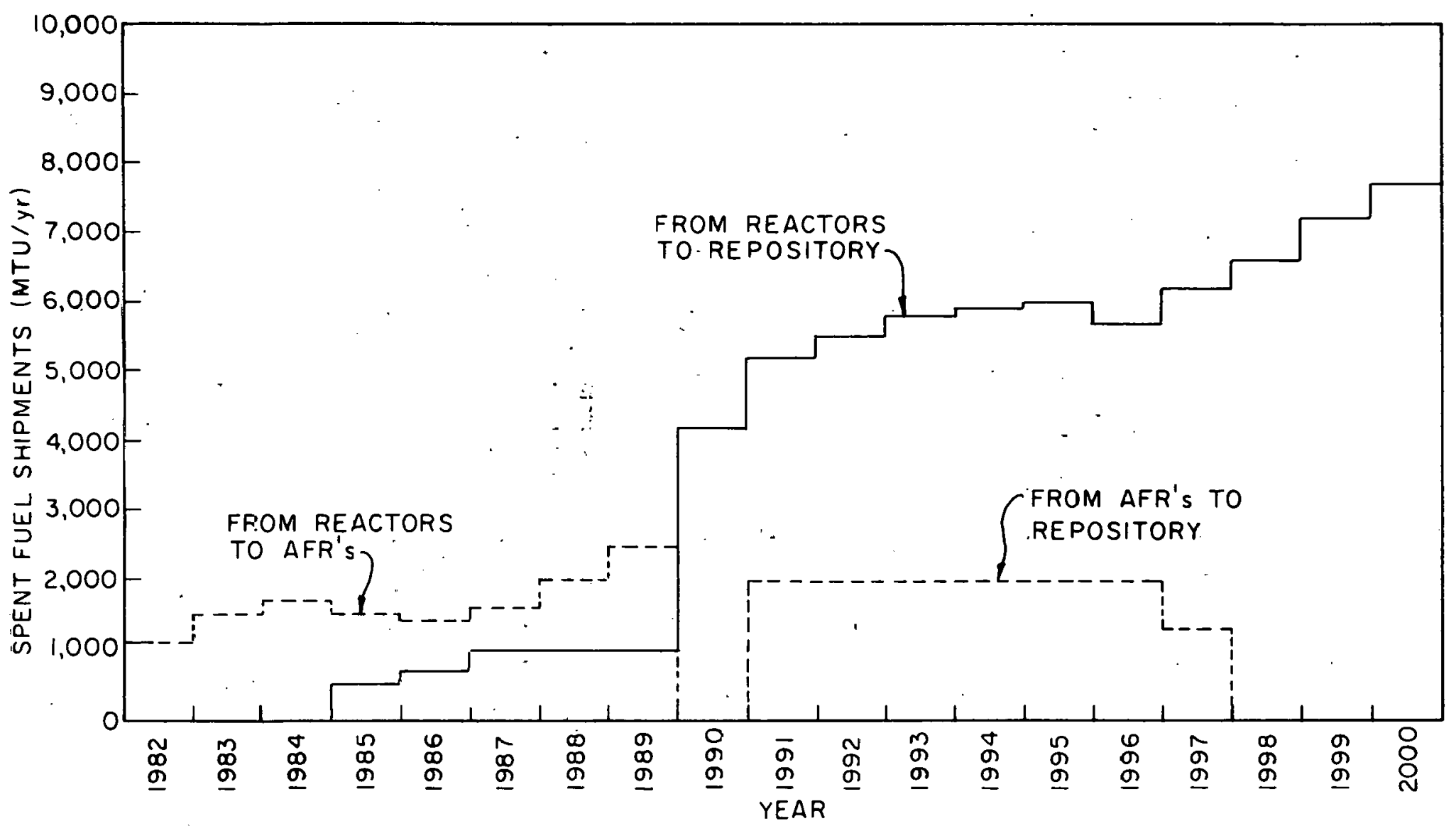

Fig. 3.1. Projected annual spent fuel shipments. 
(5) the study will consider a time period of 19 years (1982-2000), at which time the repository will be filled at its capacity.

Transportation costs were developed for shipping spent fuel from each nuclear reactor site to the four AFR facilities and to the appropriate repository. If a reactor site has access to a rail line, all shipments were assumed to be made by rail; otherwise, truck shipments were used to move the spent fuel from the reactor to its destination. All rail casks were assumed to be similar to the IF-300 cask and would carry 7 PWR assemblies or 18 BWR assemblies. Only full-cask loads were considered. For truck shipments, only legal-weight shipments were considered-each shipment moving I PWR or 2 BWR assemblies. All shipments from the AFR facility to the repository were assumed to be rāil shipmeni utiliziù à cask similar to the IF-30n cask. It was also assumed that special trains would be required for moving luaded iail casks, and the empty casks wöuld be returned as yential freight. A $\$ 21 /$ milo sharge for sperial trains was included in the overall transportation charges. The number of casks transported by the special trains is assumed to be a function of the distance between the reactor and destination as shown below:

$\begin{array}{cc}\begin{array}{c}\text { Distance } \\ \text { (miles) }\end{array} & \begin{array}{c}\text { Number of cars } \\ \text { per special train }\end{array} \\ 5500 & 1 \\ 501 \text { to } 1000 & 2 \\ 1001 \text { to } 2000 & 3 \\ >2000 & 4\end{array}$

All transportation costs for the shipments from the AFR facilities to the repository were obtained from railroad persunnel who would be involved in the specific haul. All special trains involved in the shipment from the AFR facilities were assumed to transport four rail casks.

Other economic parameters needed to complete the definition of the problem include:

(1) storage charge at AFR facilities, $\$ 15,000 / \mathrm{MTU}$-year; (2) cask lease chargc of approximately $\$ 2450 /$ day for rail casks and $\$ 280 /$ day for truck casks; (3) average carrier speed-rail, $7 \mathrm{mph}$; truck, $35 \mathrm{mph}$; and (4) combined cask loading and unloading time-rail, $120 \mathrm{hr}$; truck, $72 \mathrm{hr}$.

This case considered the repository to be located in the Interior Gulf Coast Salt Domes of Minden, La. Results indicated that only three of the four available AFR facilities were utilized to store spent fuel prior to 1990. After this date, however, all fuel was sent directly to the repository. The AFR facility located in the northeastern part of the U.S. was not used. The storage inventory at the other three AFR facilities is shown as a function of time in Fig. 3.2. The amount of spent fuel being shipped to each AFR facility is shown in Tables 3.1 to 3.3 . 
ORNL DWg 78-682

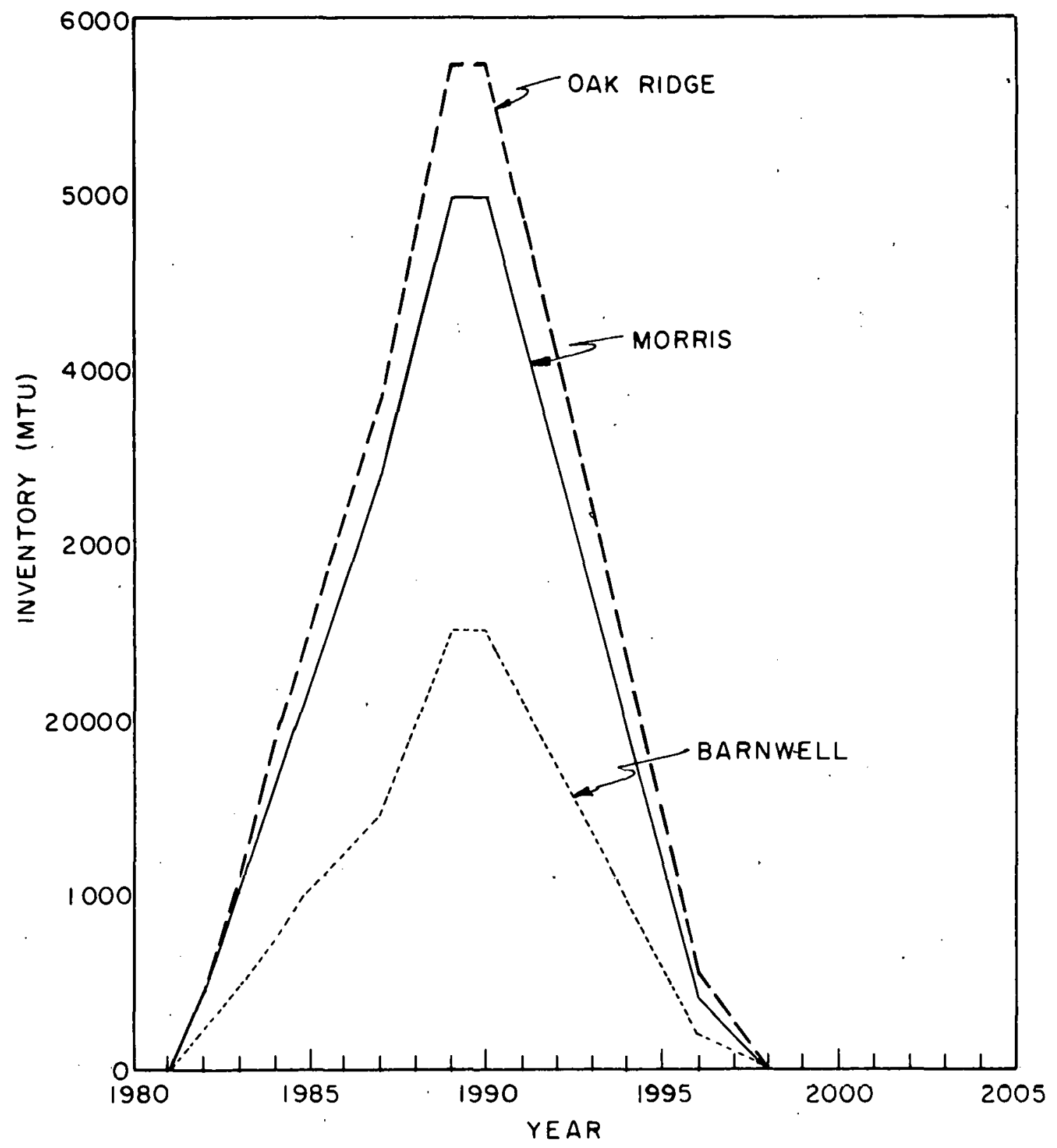

Fig. 3.2. Spent fuel stored at AFR facilities. 
Table 3.1. Amount of spent fuel shipped to AFR No. I (Morris, IL) from individual generating sites (MTU).

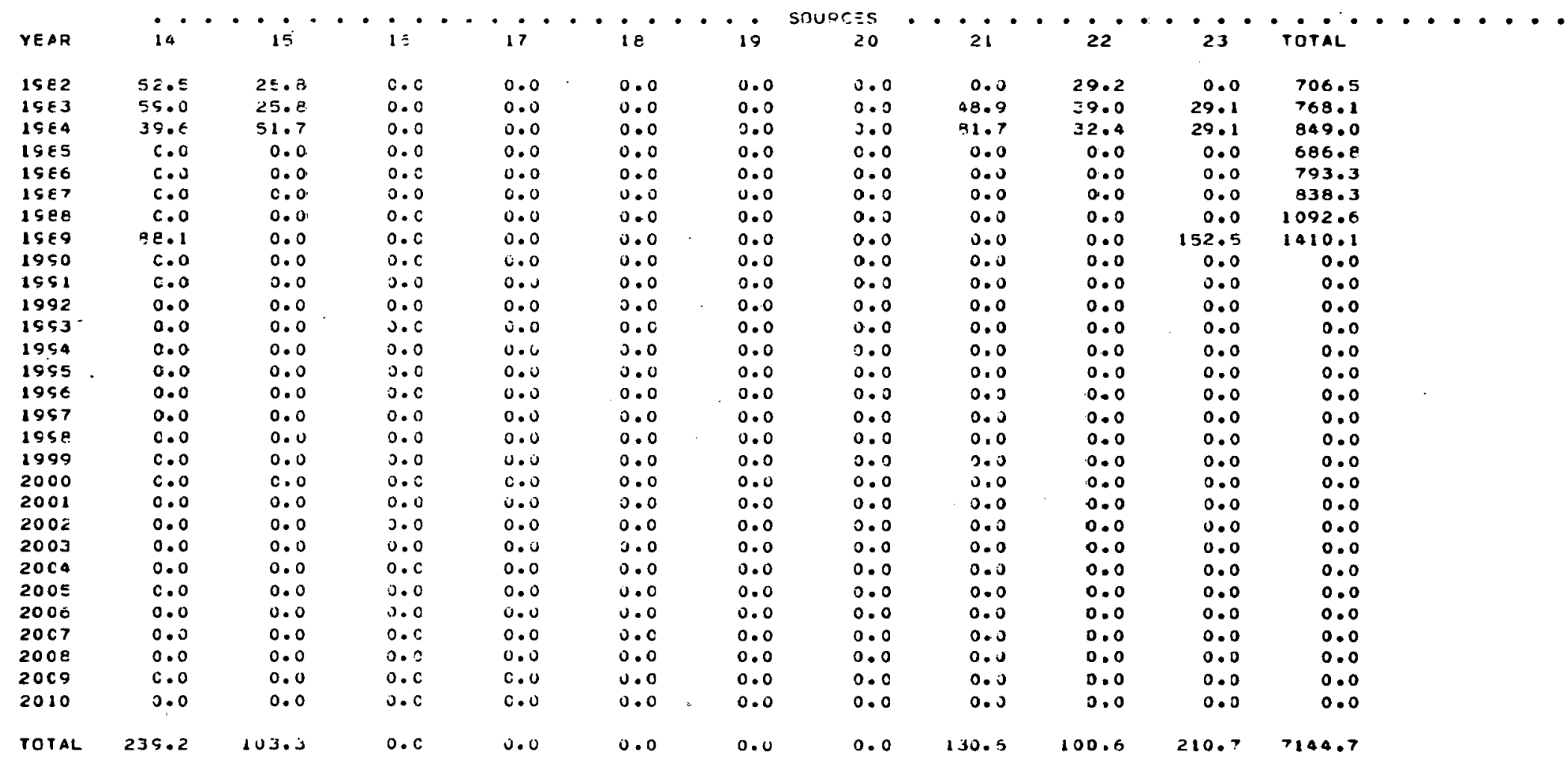


Table 3.1. (Continued)

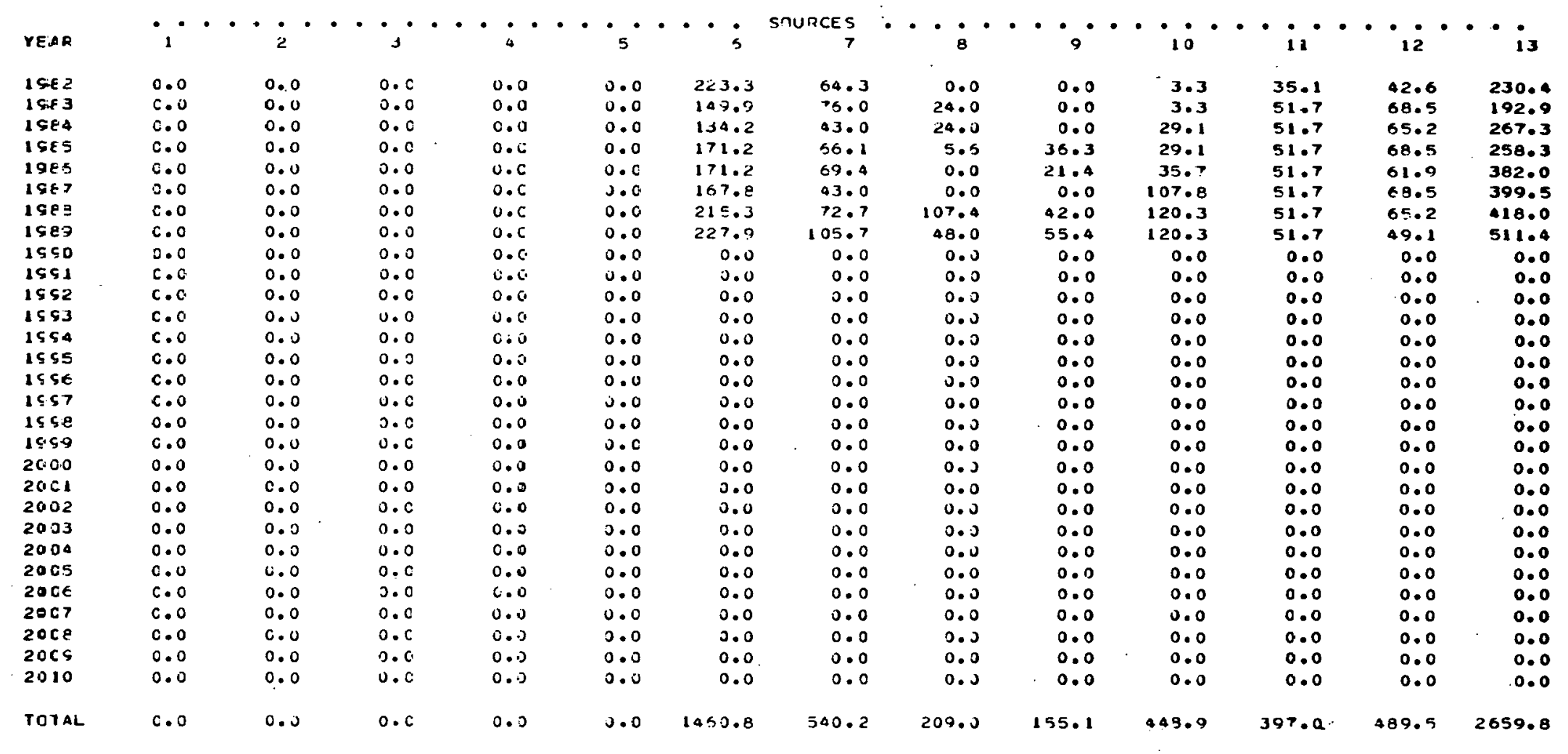


Table 3.2. Amount of spent fuel shipped to AFR No. 2 (Barnwe11, S.C.) from individual generating sites (MTU).

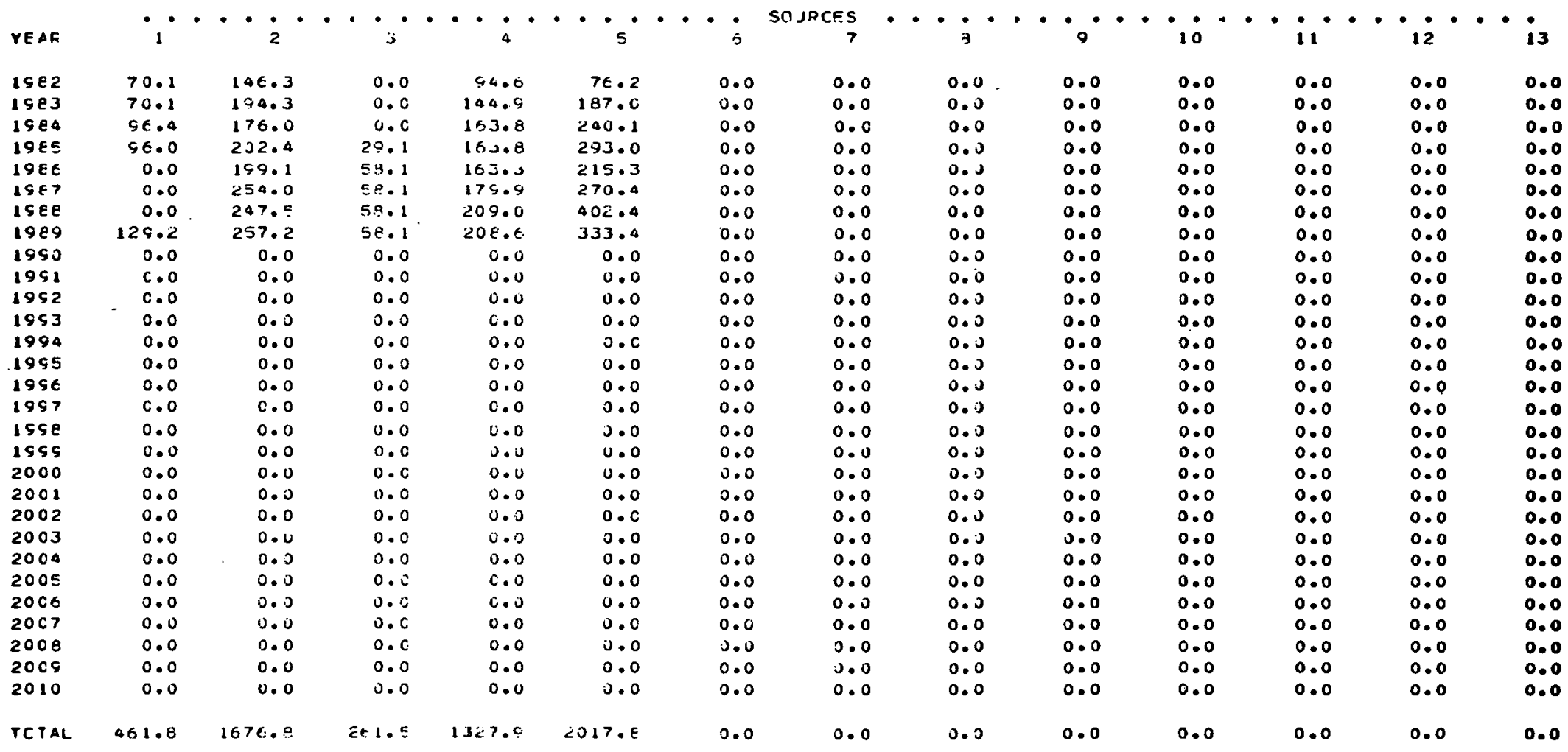


Table 3.2. (Continued)

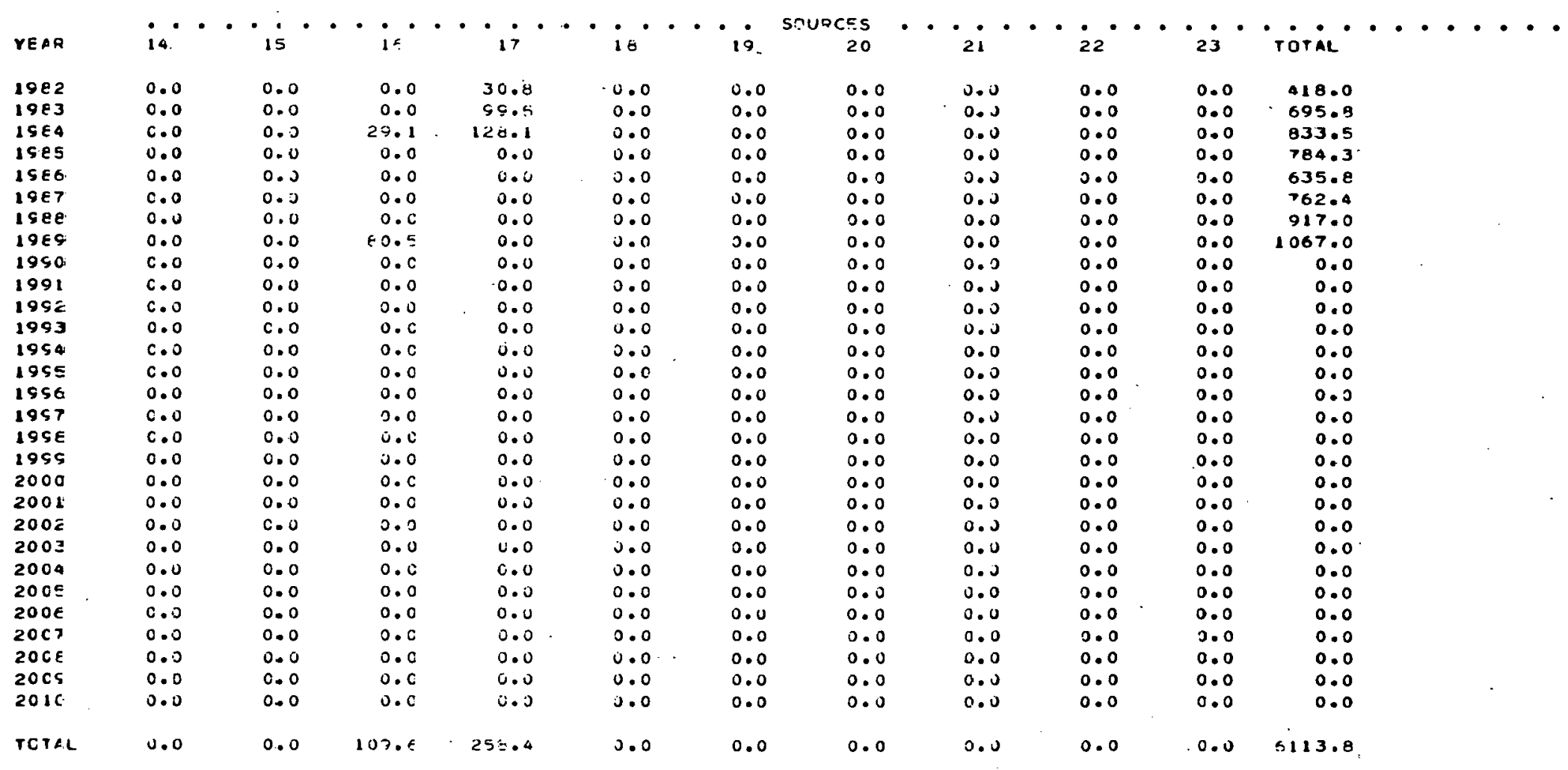


Table 3.3. Amount of spent fuel shipjed to AFR No. 3 (Oak Ridge, TN) from individual generating sites (MTU).

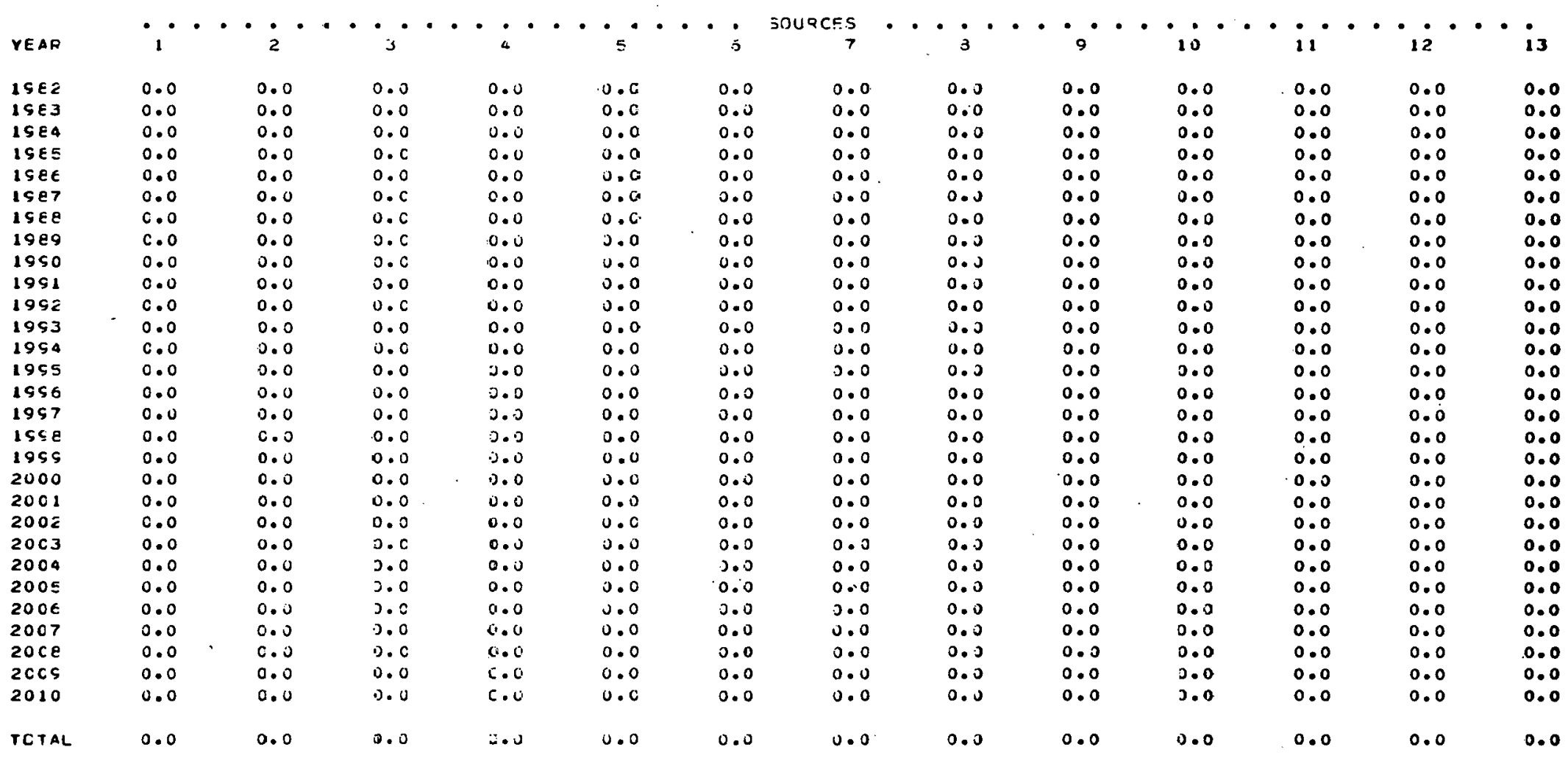


Table 3.3. (Continued)

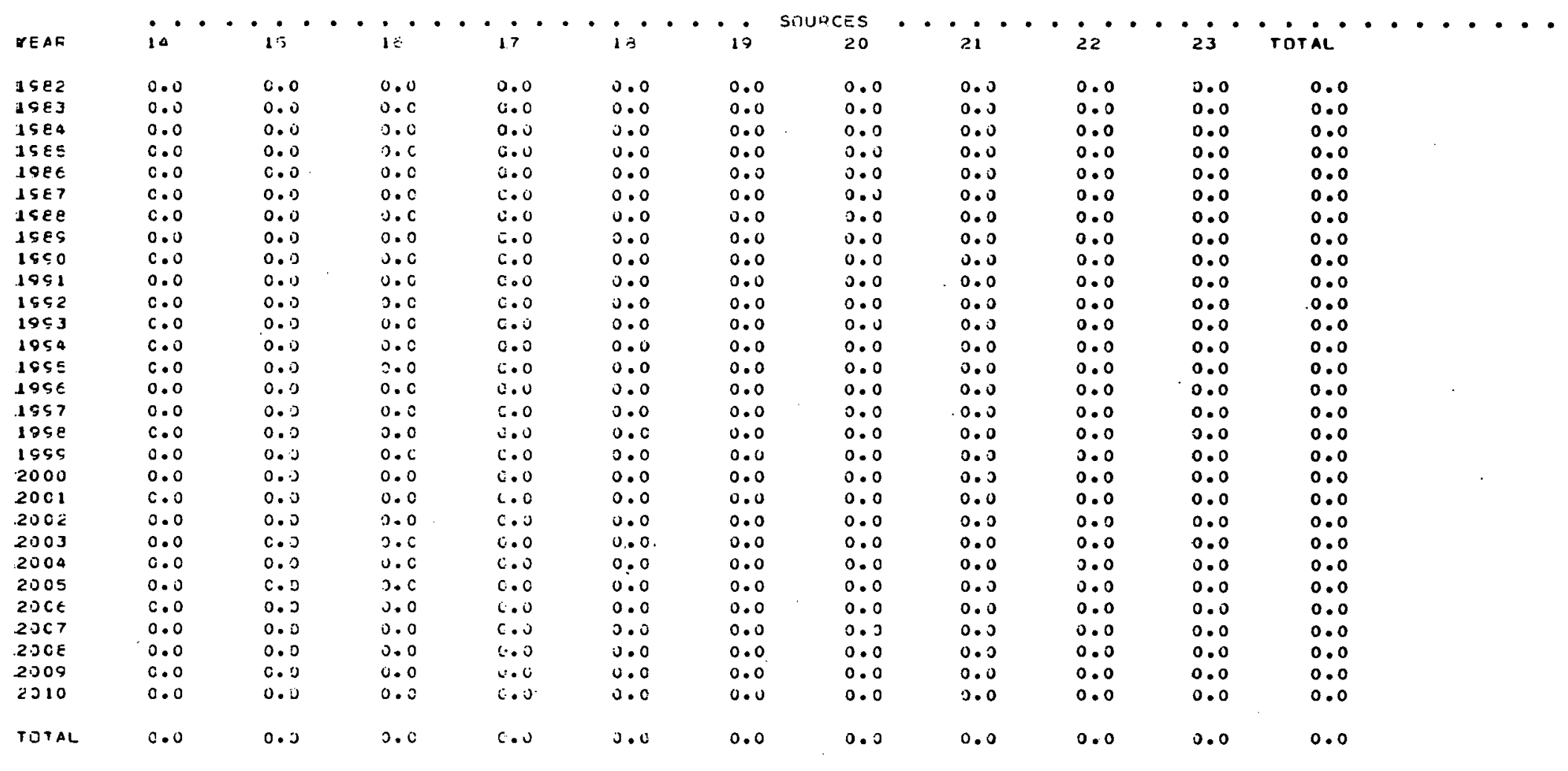


Several interesting shipping decisions enter into the problem when the repository opens in 1985. Between the years 1985 and 1989 , the amount of spent fuel which can be sent directly to the repository is constrained. The optimization calculations minimized total system costs. In this case, it would be preferable to ship directly to the repository, since a single shipment is always less expensive than making two shipments which would be required if the fuel was sent to an AFR facility. In order to determine which generating sites will actually ship directly to the repository, the incremental costs which would be incurred if the shipment was diverted to an AFR facility must be considered. For this case, the generating sites (Regions 20-23) located in the western U.S. will ship directly to the repository, while the sites in the eastern part of the country continue to send their spent fuel to an AFR facility.

It is Important to point out that the shipping decisions and relative use of the AFR facilities are a strong function of the repository location. General conclusions as to how spent fuel would be transported and the desirability of specific AFR facility locations cannot be made from a single case study.

The number of rail and truck shipping casks required to move the spent fuel to the optimum destination is summarized in Figs. 3.3 and 3.4. The growth curve for both rail and truck casks follow the same general pattern. Between 1982 and 1989, there is a reasonable increase in the respective cask fleet requirements. However, in 1990, there is a sharp increase in the number of casks required. In that year, the AFR is closed, and all of the spent fuel must be sent to the repository. This means a longer shipment is required from the generating sites who, in the previous year, were shipping spent fuel to an AFR facility. The number of casks needed take an even greater jump in 1991. This is caused by two factors: (1) the AFR facilities are beginning to ship stored fuel to the repository at a combined rate of $2000 \mathrm{MTU} /$ year (approximately 31 rail casks are needed to make these shipments); and (2) the generating sites are starting to ship the backlog of pre-1977 fuel to the repository, which requires an additonal 7 to 9 rail casks. The cask fleet requirements drop sharply in 1977 when the shipments from the ArK facilities are completed, and the backlog of pre-1977 fuel has been exhausted. The same reasoning applies to the number of truck casks required except that, since it was assumed that only rail shipments would be made from the AFR's to the repository, no truck casks were needed for that function. Again, location of the repository has a strong influence on the cask fleet requirements; hence, different repository locations, the cask fleet requirements will change significantly.

\section{SPENT FUEL SHIPMENT PROGRAM}

I'he Spent Fuel Shipment Program is designed to predict the annual spent fuel shipments from each nuclear reactor in the U.S. A general outline of the program is presented in Sect. 4.1, and a detailed description of the calculations performed is included in Sect. 4.2. Sections 4.3 and 4.4 discuss data requirements and the organization of results respectively. 
ORNL DWg 78-680

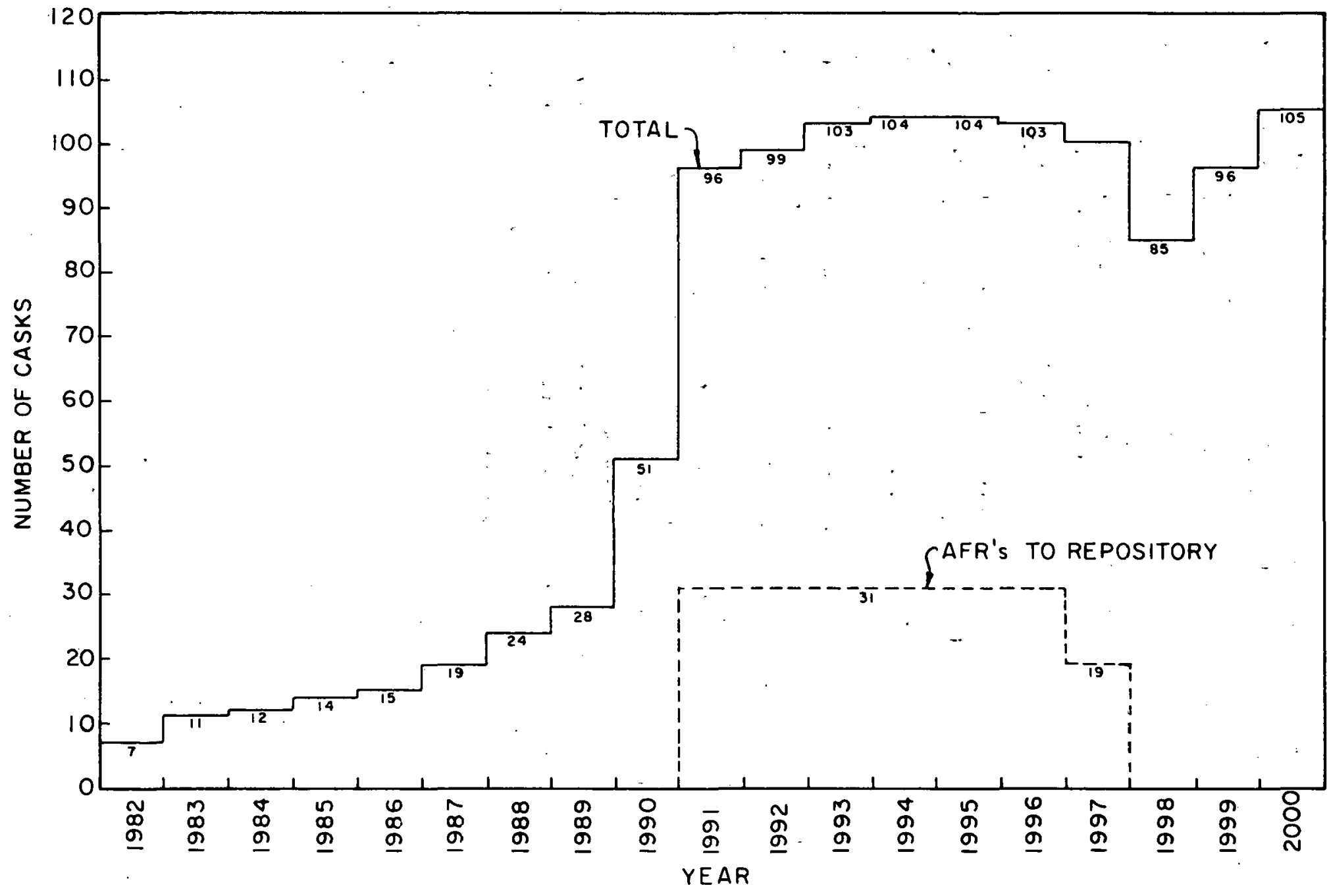

Fig. 3.3. Estimated rail cask fleet size. 
ORNL DWg 78-679

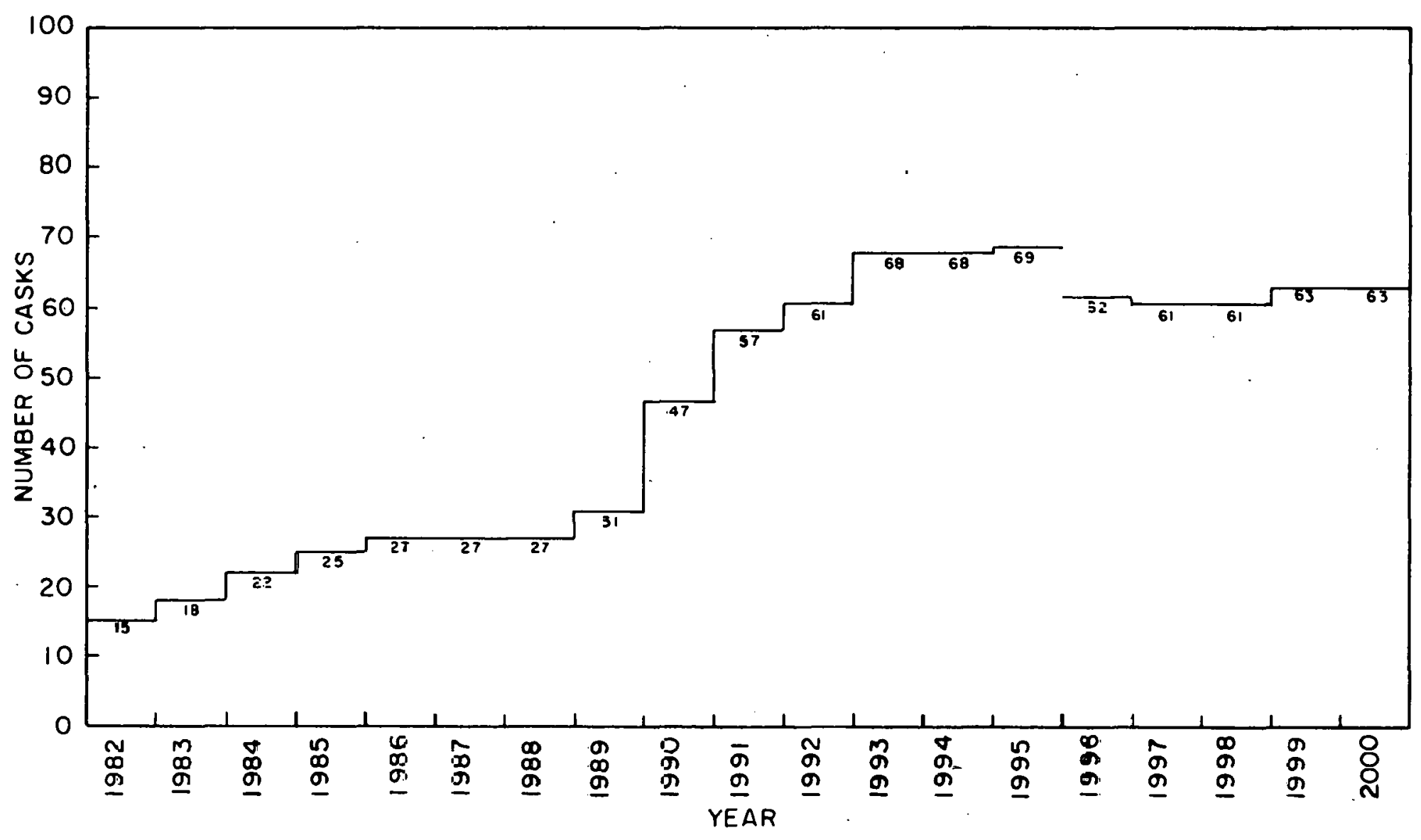

Fig. 3.4. Estimated truck cask fleet size. 


\subsection{Program Description}

The Spent Fuel Shipment Program estimates the number of spent fuel assemblies transported annually from a nuclear reactor site to an AFR storage facility or a federal repository. The program also calculates (1) the number of rail or truck shipments required to move spent fuel from both pressurized water reactors (PWR) and boiling water reactors (BWR), and (2) the number of casks needed to make the required shipments to a predefined destination.

Several parameters, which can be varied in the program, have a direct influence on the calculated amount of spent fuel shipped annually from a reactor site. These parameters include: (1) the year in which a storage facility will begin receiving spent fuel, (2) the minimum age of the fuel which will be accepted, and (3) the manner in which the backlog of long-cooled spent fuel will be worked off. The number of rail or truck shipments required to move the spent fuel is determined by the capacity of the spent fuel casks assumed. Both PWR and BWR rail and truck casks are considered. The estimate of the number of casks required is a function of the distance to the storage facility, the average carrier speed, the cask handling delays, and the cask availability during the year.

Each reactor is treated as a separate unit by the program. Output information generated by the program indicates the exact number of spent fuel assemblies moved, the mode by which it is moved, and the total number of casks needed to service all U.S. reactors.

For reasons that will be enumerated below, it is convenient to divide all U.S. reactors into groups or regions. Each region will typically contain several reactors within a relatively small geographic area. Up to 30 regions can be identified by specifying the reactors contained within that region. The information described in the previous paragraph is also reported for each of the regions defined. By having the regions identical with the grouping used in the Spent Fuel Logistics Model (Sect. 3.1), the Spent Fuel Shipment program will generate part of the input data required by the logistics model, namely the metric tons of heavy metal shipped annually from each generating region.

In addition to supplying information to the Spent Fuel Logistics Model, the Spent Fuel Shipment program can be used for simplified logistics problems. For example, the program calculates the size of the cask fleet needed to move spent fuel to predefined destinations. Any number of destinations can be chosen around the U.S. The program assumes all spent fuel is shipped to a single destination and repeats the cask fleet calculations for each destination defined. If desired, the program is capable of considering a situation where different generating regions ship fuel to different destinations.

\subsection{Mathematical Basis}

Results calculated by the program are based on annual spent fuel discharge information for all U.S. reactors which have operated, are operating, or will operate between now and the year 2010. This information is available in the Nuclear Reactor Data Base that is described in Chapt. 5.

In order to demonstrate the mathematical basis of the program, a sample calculation is presented in Tahle 41 
T:ble 4.1. Sample calculaticn of annual spent fuel shipment

\begin{tabular}{|c|c|c|c|c|c|c|c|c|}
\hline Year & $\begin{array}{l}\text { Spent fuel } \\
\text { discharges, } \\
\text { assemblies }\end{array}$ & $\begin{array}{l}\text { Assen } \\
5-y r^{r}-01 d \\
\text { fuel }\end{array}$ & $\begin{array}{l}\text { es to be } \\
\text { Backlog } \\
\text { fuel }\end{array}$ & Total & $\begin{array}{c}\text { Actual sh } \\
\text { Assemblies }\end{array}$ & Mts & $\begin{array}{l}\text { Number } \\
\text { of rail } \\
\text { shipments }\end{array}$ & $\begin{array}{l}\text { Number of } \\
\text { rail casks } \\
\text { required }\end{array}$ \\
\hline $\begin{array}{l}1976 \\
1977 \\
1978 \\
1979 \\
1980 \\
1981 \\
1982 \\
1983 \\
1984 \\
1985 \\
1986 \\
1987 \\
1988 \\
1989 \\
1990 \\
1991 \\
1992 \\
1993 \\
1994 \\
1995 \\
1996 \\
1997 \\
1998 \\
1999 \\
2000\end{array}$ & $\begin{array}{r}0 \\
0 \\
52 \\
104 \\
104 \\
104 \\
104 \\
104 \\
104 \\
104 \\
104 \\
104 \\
104 \\
104 \\
104 \\
104 \\
104 \\
104 \\
104 \\
104 \\
104 \\
104 \\
104 \\
104 \\
104\end{array}$ & $\begin{array}{l}- \\
\bar{Z} \\
\bar{Z} \\
\bar{Z} \\
\overline{-} \\
\overline{104} \\
104 \\
104 \\
104 \\
104 \\
104 \\
104 \\
104 \\
104 \\
104 \\
104 \\
104 \\
104 \\
104 \\
104 \\
104\end{array}$ & $\begin{array}{c}- \\
- \\
- \\
- \\
\bar{Z} \\
- \\
- \\
0 \\
0 \\
0 \\
0 \\
0 \\
0 \\
31 \\
31 \\
31 \\
31 \\
32 \\
0 \\
0 \\
0 \\
0 \\
0\end{array}$ & $\begin{array}{l}\bar{C} \\
\overline{-} \\
\overline{-} \\
\overline{-} \\
\overline{-} \\
\overline{-} \\
104 \\
104 \\
104 \\
104 \\
104 \\
104 \\
135 \\
135 \\
135 \\
135 \\
136 \\
104 \\
104 \\
104 \\
104 \\
104\end{array}$ & $\begin{array}{l}- \\
- \\
- \\
- \\
- \\
- \\
- \\
98 \\
105 \\
105 \\
105 \\
105 \\
105 \\
133 \\
133 \\
140 \\
133 \\
133 \\
105 \\
105 \\
105 \\
105 \\
105\end{array}$ & $\begin{array}{l}- \\
- \\
- \\
- \\
- \\
- \\
- \\
- \\
45.22 \\
48.45 \\
48.45 \\
48.45 \\
48.45 \\
48.45 \\
61.37 \\
61.37 \\
64.60 \\
61.37 \\
61.37 \\
48.45 \\
48.45 \\
48.45 \\
48.45 \\
48.45\end{array}$ & $\begin{array}{l}\overline{-} \\
\overline{-} \\
\overline{-} \\
\overline{-} \\
\overline{-} \\
\overline{-} \\
14 \\
15 \\
15 \\
15 \\
15 \\
15 \\
19 \\
19 \\
20 \\
19 \\
19 \\
15 \\
15 \\
15 \\
15 \\
15\end{array}$ & $\begin{array}{l}- \\
- \\
- \\
- \\
- \\
- \\
- \\
\overline{1} \\
1.32 \\
1.41 \\
1.41 \\
1.41 \\
1.41 \\
1.41 \\
1.79 \\
1.79 \\
1.88 \\
1.79 \\
1.79 \\
1.41 \\
1.41 \\
1.41 \\
1.41 \\
1.41\end{array}$ \\
\hline
\end{tabular}


The reactor site chosen contains two PWR reactors that share a common spent fuel storage pool. Such reactors are considered as a single generating source. The number of assemblies discharged annually by the reactors is shown in the second column of Table 4.1 (spent fuel discharge). Discharge data contained in the data base cover a time span between 1961 and 2010. However, for convenience, only the years 1975-2000 are shown in Table 4.1.

The AFR storage facility is assumed to receive 5-year-old (or older) fuel beginning in 1985. Therefore, in that year, the reactor will begin shipping fuel that was discharged in 1980 . In 1986, fuel disharged in 1981 will be shipped. All fuel discharged prior to 1980 (in this case, the 156 assemblies indicated in Table 4.1) is classified as spent fuel backlog. Theoretially, this fuel could be sent to a receiving facility in 1985 since it has been aged more than five years. However, to prevent a large surge of spent fuel arriving at the AFR during the first year of operations, all backlogged fuel was assumed to be shipped at a uniform rate between 199l and 1995. The third column in Table 4.1 lists the shipments of 5-year-old fuel from the reactor, and the fourth column lists the shipments of the backlogged fuel. The total amount of fuel to be shipped from the reactor is shown in the fifth column.

All spent fuel shipments will be made in shielded casks. The actual number of fuel assemblies sent to a storage facility is determined by considering the cask capacity and mode of transportation utilized. Three options have been included in order to model a wide range of scenarios. The three options are:

(1) full cask loads and a single mode of transportation,

(2) full cask loads and mixed modes of transportation, and

(3) partial cask loads and a single mode of transportation.

The first option will only utilize full cask loads, and any fuel not shipped will be held over until the next year. All reactors with rail access are assumed to make all shipments by rail; the remaining reactors are assumed to utilize truck shipments. The data shown in Table 4.I were generated by assuming rail shipments that use a cask capable of carrying seven PWR assemblies. The number of assemblies actually shipped from the reactor, the corresponding metric tons of heavy metal, and the number of shipments made are shown in columns 6,7 , and 8 respectively.

The second shipping option would ship as much fuel as possible by rail and then ship the remaining fuel by truck. This option reduces the amount of fuel that must be stored at the reactor until the next year while still utilizing only full-load shipments. Hence it is conceivable that a few assemblies would not be shipped in a given year. For the results shown in Table $4.1,104$ assemblies are to be shipped in 1985. Using option 1, 14 rail shipments (98 assemblies) are made, and shipment of the remaining 6 assemblies are deferred until 1986. If option 2 was selected, 98 assemblies would still be shipped by rail with the remaining 6 assemblies being shipped by truck. Assuming a truck cask could handle only a single PWR assembly, an additional 6-truck shipment would be scheduled for this reactor.

The third option utilizes a single mode of transportation but will move all fuel scheduled to be shipped in a given year even if a partial load must be utilized. In practice, this option would probably not be cost effective, but it was included to cover all possible shipping scenarios. For the results shown in Table 4.1, 14 rail shipments, which move 98 assemblies, are schcduled in 1985. Using the third option, an extra rail shipment would be added to remove the other 6 assemblies. 
After the total number of assemblies shipped each year has been determined, the program calculates the metric tons of heavy metal transported assuming each PWR assembly contains $461 \mathrm{~kg}$ of heavy metal and each BWR assembly contains $183 \mathrm{~kg}$ of heavy metal.

The final step in the calculations estimates the number of shipping casks required to make the necessary shipments shown in column 9 of Table 4.1. The distance between the reactor and storage facilities is calculated from the great circle distance between the two sites, with an additional $18 \%$ being added to reflect the realistic distance of rail and truck routes. The elapsed time to make a round trip between reactor and storage facilities is based on the distance traveled, the average speed of transport, and the estimated times for loading and unloading. The values used for these variables in the example are: one-way shipping distance, 2227 miles; average speed by rail, $7 \mathrm{mph}$, and the combined loading and unluading times, 120 hr. A rail cask would be expected to make a round trip in 31.5 days. Assuming a cask is available for service 335 days/year, 1.32 casks would be required to move the fuel in 1985 .

While not shown in the sample program, the issue of special trains can also be addressed. If the "number of casks carried in a special train is specified, the annual shipments will be grouped into an integral number of special train shipments. Special trains can be required for the entire shipment or only the shipment of loaded casks.

The calculations outlined above are made for each reactor in the Nuclear Data Base. The number of assemblies shipped, the number of rail and truck shipments, number of special trains, and the number of rail and truck casks required are summed for each region.

\subsection{Data Requirements}

A large amount of data is needed tô make the culculativis uutlined iii Scet. 4.2. All of the nuclear reactor data required are contained in The Nuclear Reactor Data Base, which is described in Chapt. 5. However, to determine the shipment schedules, additional information must be specified to describe the AFR, shipplng cusks, and lianspul laliuin inude charactcristios.

The description required for a storage facility includes:

(1) the first year that fuel is received,

(2) the minimum age of the fuel to be received,

(3) the fuel backlog and how it is to be worked off, and

(4) the locations of the storage facilities.

Several different AFR locations can be specified. However, the program assumes that iterns I through 3 apply to each location. The program calculales the number of rail and iruck cusks required to transport all the spent fuel to each location.

The capacity of each shipping cask used to transport the spent fucl from the reactor to an AFR must be supplied. The program considers only four different types of casks: PWR rail cask, PWR truck cask, BWR rail cask, and BWR truck cask. For each type of cask, the number of assemblies carried per trip and the cask availabilities in days/year, are required. For each mode of transport, the average speed and loading-unloading times must be specified. 


\subsection{Program Output}

The first part of the program output lists all reactors in each of the nuclear generating regions that were defined. The number of spent fuel assemblies shipped annually by each reactor is also included. F,or each region considered, a series of tables summarize the following information for each year of the study:

(1) total electrical generation capacity of PWR reactors,

(2) total electrical generation capacity of BWR reactors, .

(3) PWR assemblies shipped,

(4) BWR assemblies shipped,

(5) total metric tons of heavy metal shipped,

(6) number of PWR rail shipments,

(7) number of PWR truck shipments,

(8) number of BWR rail shipments, and

(9) number of BWR truck shipments.

For each AFR receiving facility defined, an additional series of tables provide the following information:

(1) number of PWR rail casks required,

(2) number of PWR truck casks needed,

(3) number of $B W R$ rail casks required, and

(4) number of BWR truck casks needed.

Some additional information is also compiled to let the user know if the input data were prepared properly. This listing includes names of reactors which were defined to be in more than one region and those reactors which were not assigned to any region.

For completeness, a final table shows the input data used to make the calculations and includes the following:

(1) minimum storage period prior to shipment,

(2) first-year shipments are allowed,

(3) method of working off backlog,

(4) shipment policy selected,

(5) description of shipping casks, and

(6) characteristics of modes of transportation. 


\section{NUCLEAR REACTOR DATA BASE}

A computerized data base describing all U.S. nuclear power plants, whether operating, under construction, or on order as of March 1, 1977, has been established. The data base contains a total of 208 entries and includes the following information for each reactor: ${ }^{2-5}$

(1) reactor name,

(2) location of reactor (city, county, and state);

(3) operating utility,

(4) type of reactor,

(5) electrical generating capacity,

(6) date of actual or expected commercial operation,

(7) transportation modes available at reactor site (truck, rail, and/or barge),

(8) spent fuel storage capacity,

(9) actual and projected spent fuel discharges between 1961 and 2010 for these reactors, and

(10) reactor coordinates (latitude and longitude).

An example of the data base information is shown in Table 5.1 for four reactors: Byron-1, Byron-2, Braidwood-1, and Braidwood-2.

Bryon-1 and Byron-2 are identical 1120-MW PWR reactors sharing a common spent fuel storage pool. The reactors are owned and operated by Commonwealth Edison Corporation and are located in Ogle County approximately 4 miles south of Byron, Ill. (Byron-1 is expected to be operational in October 1980, and the first spent fuel discharge is expected in 1981). Annual discharge of 64 assemblies are anticipated. Byron-2 will begin commercial operation in October 1982, with its first spent fuel discharge occurring in 1983. Both reactors will share a common spent fuel storage pool with a usable capacity of 564 assemblies.

The reactor locations are also included $\left(42.049^{\circ} \mathrm{N}, 89.312^{\circ} \mathrm{W}\right)$. The latitude and longitude actually refers to the centroid of Ogle County rather than the precise location of the reactor. However, reasonably accurate shipping distances can be estimated using this information because typically the distance between the reactor and the centroid of the county is small.

\section{SUUMMARY}

Development and testing of several mathematical models for optimizing radioactive waste shipments has been completed. These models will play a major role in providing information for radioactive waste program planning and long-range management activities.

Two logistics models have been developed: the Low-Level Waste Model and the Spent Fuel Logistics Model. Both models are now operational on the ORNL computer system. While each model was designed to simulate a particular waste movement, either model could be used to optimize the shipment of any commodity which would be shipped within the specific constraints outlined. 
TABLE 5.1.

SAMPLE OF NUCLEAR DATA BASE INFORMATION

64 BYRON-1

BYRON (4 MI S)

OGLE

ILL

$\begin{array}{rrrrrrrrrr} & \text { PWR } & & 1120 & 10 & 1980 & \text { TR } & 564 & & 65 \\ 0 & 0 & 0 & 0 & 0 & 0 & 0 & 0 & 0 & 0 \\ 0 & 0 & 0 & 0 & 0 & 0 & 0 & 0 & 0 & 0 \\ 0 & 64 & 64 & 64 & 64 & 64 & 64 & 64 & 64 & 64 \\ 64 & 64 & 64 & 64 & 64 & 64 & 64 & 64 & 64 & 64\end{array}$

42.049

89.312

65 BYRON-2

BYRON ( 4 MI S)

OGLE

PWR 11

12010 COMMONWEALTH EDISON

ILL

$\begin{array}{rrrrrrrrrrr} & \text { PWR } & 1120 & 10 & 1982 & \text { TR } & & 0 & & 64 & \\ 0 & 0 & 0 & 0 & 0 & 0 & 0 & 0 & 0 & 0 \\ 0 & 0 & 0 & 0 & 0 & 0 & 0 & 0 & 0 & 0 \\ 0 & 0 & 64 & 64 & 64 & 64 & 64 & 64 & 64 & 64 \\ 64 & 64 & 64 & 64 & 64 & 64 & 64 & 64 & 64 & 64 \\ 42.049 & 89.312 & & & & & & \end{array}$

66 BRAIDWOOD -1

BRAIDWOOD

WILL

ILL

$\begin{array}{rrrrrrrrrrr} & \text { PWR } & 1120 & 10 & 1981 & \text { TR } & 505 & 67 & \\ 0 & 0 & 0 & 0 & 0 & 0 & 0 & 0 & 0 & 0 \\ 0 & 0 & 0 & 0 & 0 & 0 & 0 & 0 & 0 & 0 \\ 0 & 0 & 64 & 64 & 64 & 64 & 64 & 64 & 64 & 64 \\ 64 & 64 & 64 & 64 & 64 & 64 & 64 & 64 & 64 & 64 \\ 41.463 & 87.899 & & & & & & \end{array}$

67 BRAIDWOOD-2

BRAIDWOOD

WILL

ILL

\begin{tabular}{rrrrrrrrrrr} 
& PWR & & 1120 & 10 & \multicolumn{1}{c}{1982} & TR & & 0 & 66 & \\
0 & 0 & 0 & 0 & 0 & 0 & 0 & 0 & 0 & 0 \\
0 & 0 & 0 & 0 & 0 & 0 & 0 & 0 & 0 & 0 \\
0 & 0 & 0 & 64 & 64 & 64 & 64 & 64 & 64 & 64 \\
64 & 64 & 64 & 64 & 64 & 64 & 64 & 64 & 64 & 64 \\
41.463 & 87.899 & & & & & &
\end{tabular}




\section{REFERENCES}

1. C. W. Alexander, C. W. Kee, A. G. Croff, and J. O. Blomeke, Projections of Spent Fuel to be Discharged by the U.S. Nuclear. Power Industry, ORNL/TM-6008 (October 1977).

2. "World List of Nuclear Power Plants," Nucl. News 20(3), 58-63 (1977).

3. Commercial Nuclear Power Plants,“ NUS Corp., 9th ed. (January 1977).

4. C. B. Woodhall, U.S. $L W^{\prime} R$ Spent Fuel Inventory and Projecions, Y/OWl/SUB-77/42500 (June 1977).

5. R. E. Best et al. Capabilities of U.S. Domestic Transportation Systems for the Shipment of Radioactive Wastes, Y/OWI/SUB-77/22330 (September 1977). 
ORNL/TM-6192

\section{INTERNAL DISTRIBUTION}

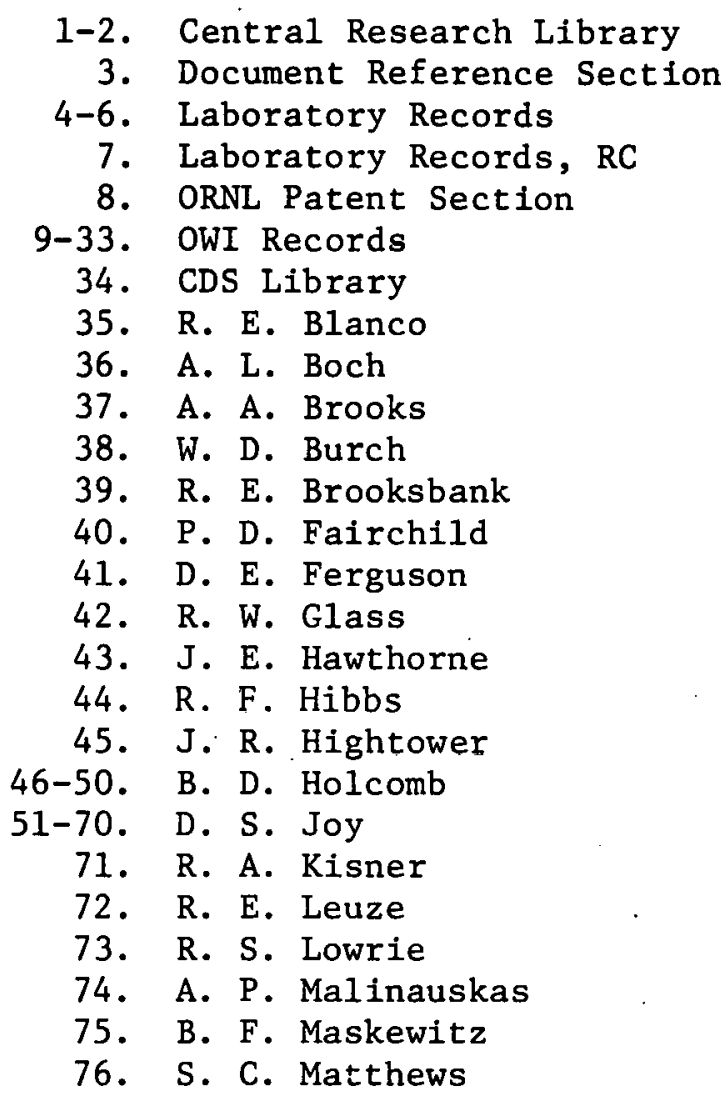

77. L. L. McCauley

78. W. C. McClain

79. R. A. McLaren

80. J. M. Morrison

81. E. Newman

82. H. M. Noritake

83. J. R. Parrott, Sr.

84. W. H. Pechin

85. H. Postma

86. A. S. Quist

87. H. N. Rosenberg

88. C. D. Scott

89. C. H. Shappert

90-91. L. B. Shappert

92. D. B. Trauger

93-97. D. W. Turner

98. J. E. Vath

99. G. W. Westly

100. R. G. Wymer

101. C. D. Zerby

102. G. R. Choppin (consultant)

103. E. L. Gaden, Jr. (consultant)

104. C. H. Ice (consultant)

105. L. E. Swabb, Jr. (consultant)

106. K. D. Timmerhaus (consultant)

\section{EXTERNAL DISTRIBUTION}

107. Department of Energy, Research and Technical Support Division, P. U. Box E', Uak Kidge, 'I'N 378'30

108-134. Department of Energy, Technical Information Center, Oak Ridge, TN 37830

135. J. D. DeSteese, Battelle, Pacific Northwest Laboratories, P. 0. Box 999, Richland, WA 99352

136. J. M. Freedman, Sandia Laboratories, P. O. Box 5800, Albuquerque, NM 87115

137. R. M. Jefferson, Sandia Laboratories, P. O. Box 5800, Albuquerque, NM 87115

138. K. E. Khoads, Battelle, Pacific Northwest Laboratories, P. 0. Box 999, Richland, WA 99352

139. J. L. Ridihalgh, Ridihalgh, Eggers \& Associates, 2112 Iuka Avenue, Columbus, $\mathrm{OH} 43201$

140-159. J. J. Schreiber, Department of Energy, Oak Ridge Operations Office, P. O. Box E, Oak Ridge, TN 37830

160. L. Scully, Sandia Laboratorles, P. 0. Box 5800, Albuquerque, NM 87115

161. D. Williams, Battelle, Pacific Northwest Laboratories, P. 0. Box 999, Richland, WA 99352 